\title{
Mapping Participatory Methods in the Urban Development Process: A Systematic Review and Case-Based Evidence Analysis
}

\author{
Devindi Geekiyanage *(D), Terrence Fernando *(i) and Kaushal Keraminiyage (i) \\ School of Science, Engineering and Environment, University of Salford, Maxwell Building, 43 Crescent, \\ Salford M5 4WT, UK; k.p.keraminiyage@salford.ac.uk \\ * Correspondence: m.d.hembageekiyanage@edu.salford.ac.uk (D.G.); t.fernando@salford.ac.uk (T.F.)
}

Citation: Geekiyanage, D.; Fernando,

T.; Keraminiyage, K. Mapping

Participatory Methods in the Urban Development Process: A Systematic Review and Case-Based Evidence Analysis. Sustainability 2021, 13, 8992. https://doi.org/10.3390/su13168992

Academic Editors: Bharat Dahiya and Jonathan Parkinson

Received: 1 June 2021

Accepted: 9 August 2021

Published: 11 August 2021

Publisher's Note: MDPI stays neutral with regard to jurisdictional claims in published maps and institutional affiliations.

Copyright: (c) 2021 by the authors. Licensee MDPI, Basel, Switzerland. This article is an open access article distributed under the terms and conditions of the Creative Commons Attribution (CC BY) license (https:// creativecommons.org/licenses/by/ $4.0 /)$.

\begin{abstract}
Despite the fact that vulnerable communities are the most affected by unplanned cities, considerably less attention has been given to involving them in urban development in order to ensure equitable outcomes. In this regard, there is an urgent need for governments to introduce and enforce processes that allow citizens, including vulnerable communities, to participate in development planning and policymaking. However, at present, there is a lack of guidance for practitioners regarding the definition of a clear purpose of community engagement and the selection of appropriate participatory methods to fulfil the set purpose. This study provides a thorough account of the participatory methods that can be used to achieve various engagement goals throughout the urban development process. This structured literature review used 71 reports published from 2000 to 2020. The review revealed 34 participatory methods, wherein most of the methods are devoted to informing, consulting and involving communities, whilst only a few methods are available for interactive public participation that supports true collaboration and empowerment. The study identified 12 purposes of community engagement in urban development, and mapped the 34 participatory methods for achieving them. The analysed case studies showed that the current community engagement practices are mainly in the pre-design and briefing stages of the urban development processes, and that most projects are aiming to achieve the 'inform' and 'consult' levels of engagement, with a few aiming to achieve the 'involve' and 'collaborate' levels. This study shows that community engagement is often overlooked during the professional design, development and post-development phases. The paper presents an onion model which can be used by practitioners to choose appropriate participatory methods based on the intended urban development phase, the engagement level and the purpose of the community engagement.
\end{abstract}

Keywords: community engagement; urban development; risk-sensitive; SDG 10; SDG 11; participatory methods; systematic review; PRISMA 2020; inclusive; purpose

\section{Introduction}

At present, 55\% of the world's population live in urban areas, and this is projected to be $68 \%$ by 2050 [1]. Urban growth is driven by many factors, such as the ever-increasing population, people's desire to settle in areas that offer a vibrant lifestyle, convenient access to services and facilities, and a good educational environment for children [2], as well as globalisation, micro-economics and regulatory frameworks that encourage migration [3]. Well-planned cities offer residents the opportunity to obtain a good quality of life with safety, a reduced fear of crime, community cohesion and economic prosperity [2]. Conversely, cities that are poorly planned, managed and governed can become centers of poverty, inequality and conflict [4]. Furthermore, the high building density and lower provision of green spaces resulting from this urban sprawl directly affect significant environmental parameters such as surface temperature, stormwater run-off and carbon 
sequestration $[5,6]$, leading to many climate-induced disasters such as floods, heatwaves, droughts and landslides [7-10].

Each urban development initiative affects not only those who invest or occupy buildings in the city but also a wider community who live and work nearby, or simply pass through or visit the area on a regular basis [2]. Therefore, it is the right of all of the affected parties, including local residents and businesses, to be actively involved in shaping the developments to reap the benefits equitably without adverse effects on anyone [11-16]. In order to address complex urban challenges and to respond to the uncertainties in urban development, a wide range of knowledge and resources is needed from multiple fields; local communities should, therefore, participate as a key stakeholder [17]. Unfortunately, in most cases, the local community is considered as inhabitants, rather than bringing them forward as an active participant in the urban planning. This poses a challenge for the achievement of equitable and sustainable developments as, generally, only governmental strategies are preferentially considered by the decision-makers. The factors that cause the exclusion of communities include their lower capacity and understanding. Communities are unwilling to participate in government-led projects due to public cynicism and distrust in the local authority processes [18]. This is further exacerbated by a range of other factors, such as the low investment for infrastructure and planning required for community engagement exercises, strictly determined top-down procedures, the lack of a participatory culture within practitioners, and their insufficient knowledge and understanding of participatory practices [18]. Therefore, there is a serious concern that the targets set by the United Nations' Sustainable Development Goals, such as Goal 10 (Reduce inequality within and among countries) and Goal 11 (Make cities and human settlements inclusive, safe, resilient and sustainable), and the priorities set by the Sendai Framework for Disaster Risk Reduction 2015-2030 may not be effectively achieved [19,20].

In this regard, there is an urgent need for governments to introduce and enforce processes that build trust within communities and allow citizens, including vulnerable groups, to participate in development planning and policymaking [21,22]. In order to achieve inclusivity in urban planning, industry practitioners (including planners) should have a proper understanding of the available participatory approaches and the true purpose of involving the public during the lifecycle of an urban development project. Partitioners need to strategically select participatory methods that suit the intended outcome of involving local communities in the different phases of urban development, from the pre-design analysis (conceptual design) to the post-development stage. This study, therefore, conducted a structured literature review and a case-based evidence analysis to investigate the following research questions:

Q1. What are the existing participatory methods that are available for community engagement?

Q2. What level of engagement can be achieved from these existing methods?

Q3. How are these community engagement methods being used in practice? Have these methods been able to achieve the intended purpose?

Q4. Are the current methods sufficient to support community engagement in the entire urban design cycle?

The study's outcomes consolidate the literature on participatory methods and their application in different phases of urban development, and thereby map the identified methods into the community engagement spectrum. The study further introduces an onion model that serves as a guide for industry practitioners who seek to select inclusive methods in each phase of urban development.

\section{Materials and Methods}

The aim of conducting a systematic review of community engagement within urban development literature was to map and assess the intellectual territory and provide evidence-based answers to the research questions based on the existing knowledge. Accordingly, the review question for the study was established as 'Which participatory methods 
would be effective for community engagement in risk-sensitive urban development?'. The PICO (Population-Intervention-Comparisons-Outcomes) framework [23] was adapted to develop the literature search strategy as shown in Figure 1.

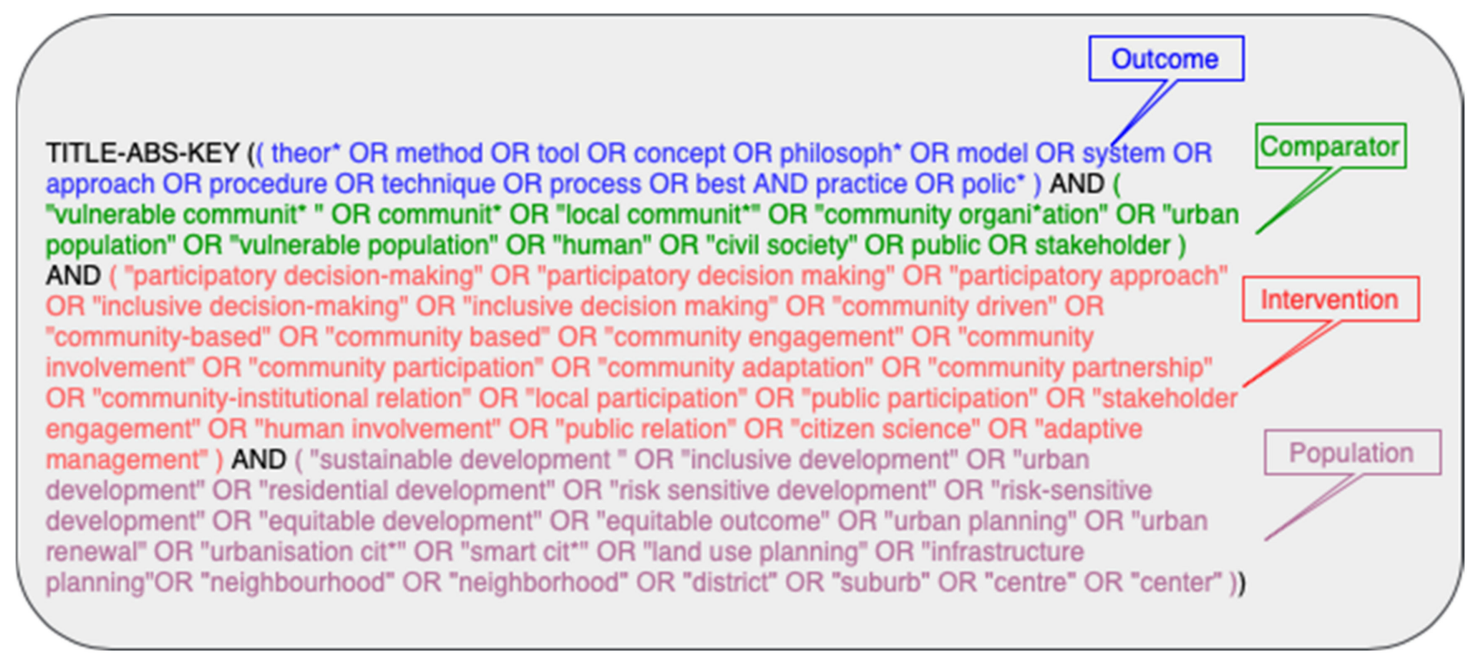

Figure 1. Literature search strategy developed for the study (source: the authors). Note: An expanded list of synonyms, keywords and index terms was included to represent the PICO terms (population-urban development; interventionparticipatory; comparator-community; outcome-method) established in the review question.

The structured literature review used records from databases as well as other sources by conducting advanced searches using the search strategy developed for the study. Initially, the studies from three universally recognised citation databases-Scopus, Web of Science and Science Direct-were searched. These databases allowed a literature search within a broad range of international scientific journals, including Sustainability, Cities, Community Development, Environmental Science \& Policy, Science of the Total Environment and Systems Research and Behavioural Science, as well as within high-ranking conference proceedings. The resulting database records were then refined by selecting the relevant filters and limits, as shown in Table 1.

Table 1. Filters assigned for the literature search (source: the authors).

\begin{tabular}{cc}
\hline Categories & Filters \\
\hline Search fields & Title, Abstract, Keywords \\
Publication year & From 2000 to 2020 \\
& Social science, Social work, Sociology, Social issues, Psychology, \\
Subject/Research area & Arts and Humanities, Urban Studies, Development Studies, \\
Decision making & Article, Proceeding's paper, Book, Book section \\
Document type & English \\
Language & A
\end{tabular}

Subsequently, a Google search was also conducted in order to identify non-journal sources such as periodic reports issued by subject-related organisations and government publications. Finally, all of the records generated from the above-mentioned databases were imported into the Endnote software for screening and systematic analysis.

The complete search found 750 records. After excluding duplicates and inappropriate records based on an initial screening of the titles, abstracts and keywords, 263 full-text reports were retrieved, and these were then assessed against the inclusion and exclusion criteria. Although 165 out of the 201 rejected reports matched the keywords and criteria used in the literature searches, they did not directly relate to community engagement practices in risk-sensitive urban development. Examples of the rejected reports included literature on biomedical science, food security and agriculture, information systems and 
education, and sources addressing stakeholders other than community. Furthermore, 36 reports that were related to community participation but which did not offer a meaningful discussion on the application of participatory methods were also excluded. This screening process resulted in the 71 research contributions which were used for the in-depth review. These final 71 reports comprised 38 case-study-based reports. The steps undertaken in the literature search are presented in Figure 2, following the updated version of the Preferred Reporting Items for Systematic Reviews and Meta-Analyse (PRISMA) method proposed in [24] for systematic reviews.

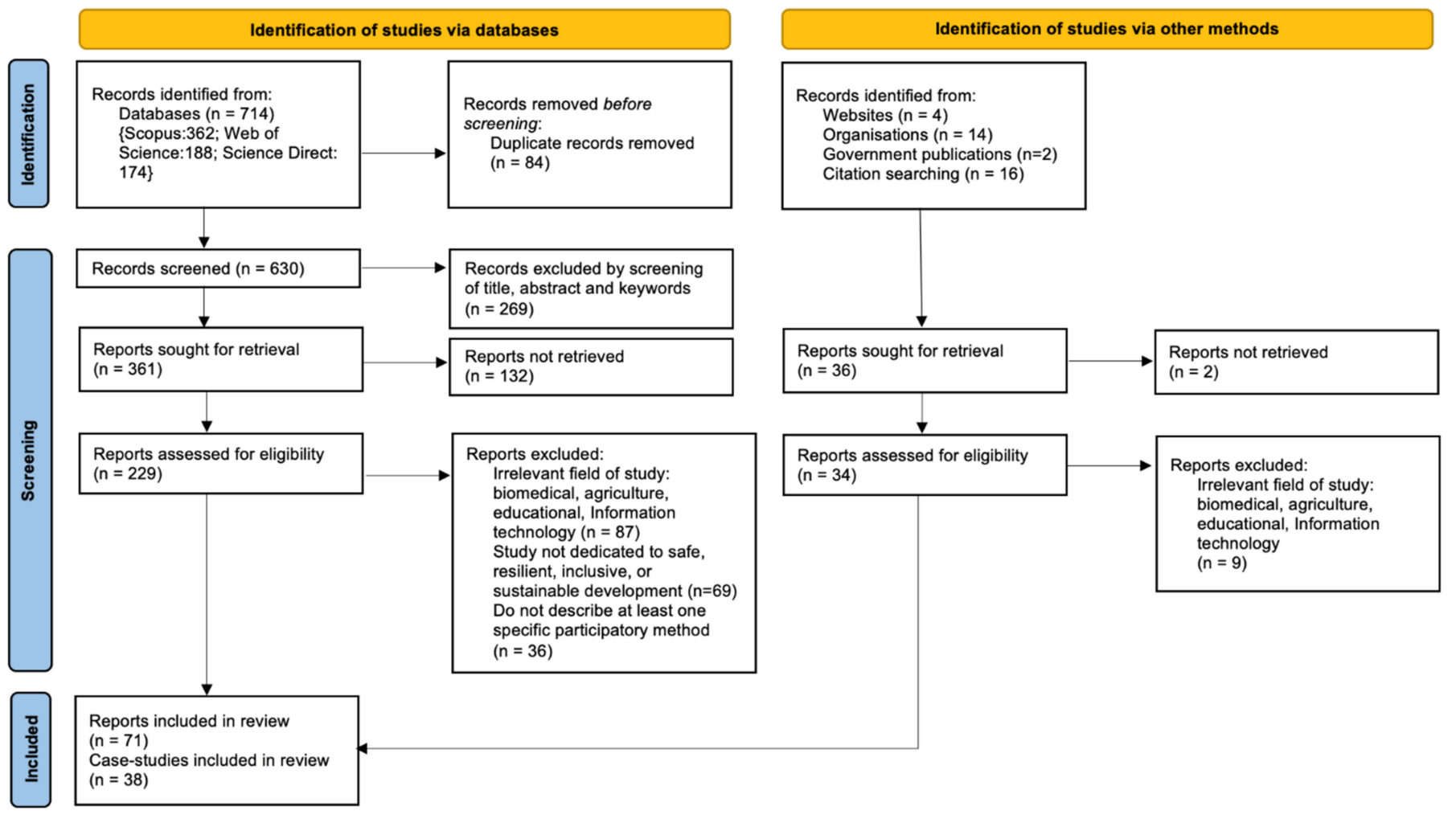

Figure 2. PRISMA 2020 flow diagram of the study (source: the authors). Note: A 'study' is an investigation, such as a case study, that includes a defined group of participants and one or more interventions and outcomes. A study might have multiple reports. A 'report' could be a journal article, preprint, conference abstract, study register entry, clinical study report, dissertation, unpublished manuscript, government report or any other document providing relevant information.

A classification of the reports based on the type of document with the year of publication is presented in Figure 3.

As shown in Figure 3a, the 71 reports used in the in-depth review can be classified as 46 indexed journal articles, 12 reports, 4 book sections, 4 web pages, 2 government publications, 2 conference papers and 1 book. Figure 3 a demonstrates the explosive growth in community engagement knowledge dissemination, particularly in urban development, over the last decade. This confirms that there has been significant scholarly and practitioner attention on inclusive decision-making in development since 2011 onwards. As shown in Figure $3 b$, the reports reviewed within the study consist of 38 case study reports, 13 theory and model development reports, 12 literature reviews and 8 other reports.

Following the systematic review, a case-based evidence analysis was carried out in order to obtain a better understanding of the ways in which participatory methods are applied in urban development globally. The interpretive case study method applied was best suited to achieve this understanding [25]. Accordingly, a total of 18 inclusive urban development scenarios discussed in the 38 case study reports were selected for the empirical evidence analysis. The inclusion and exclusion criteria adapted for the case study selection are illustrated in Figure 4. The case-based knowledge is discussed in Section 5. 


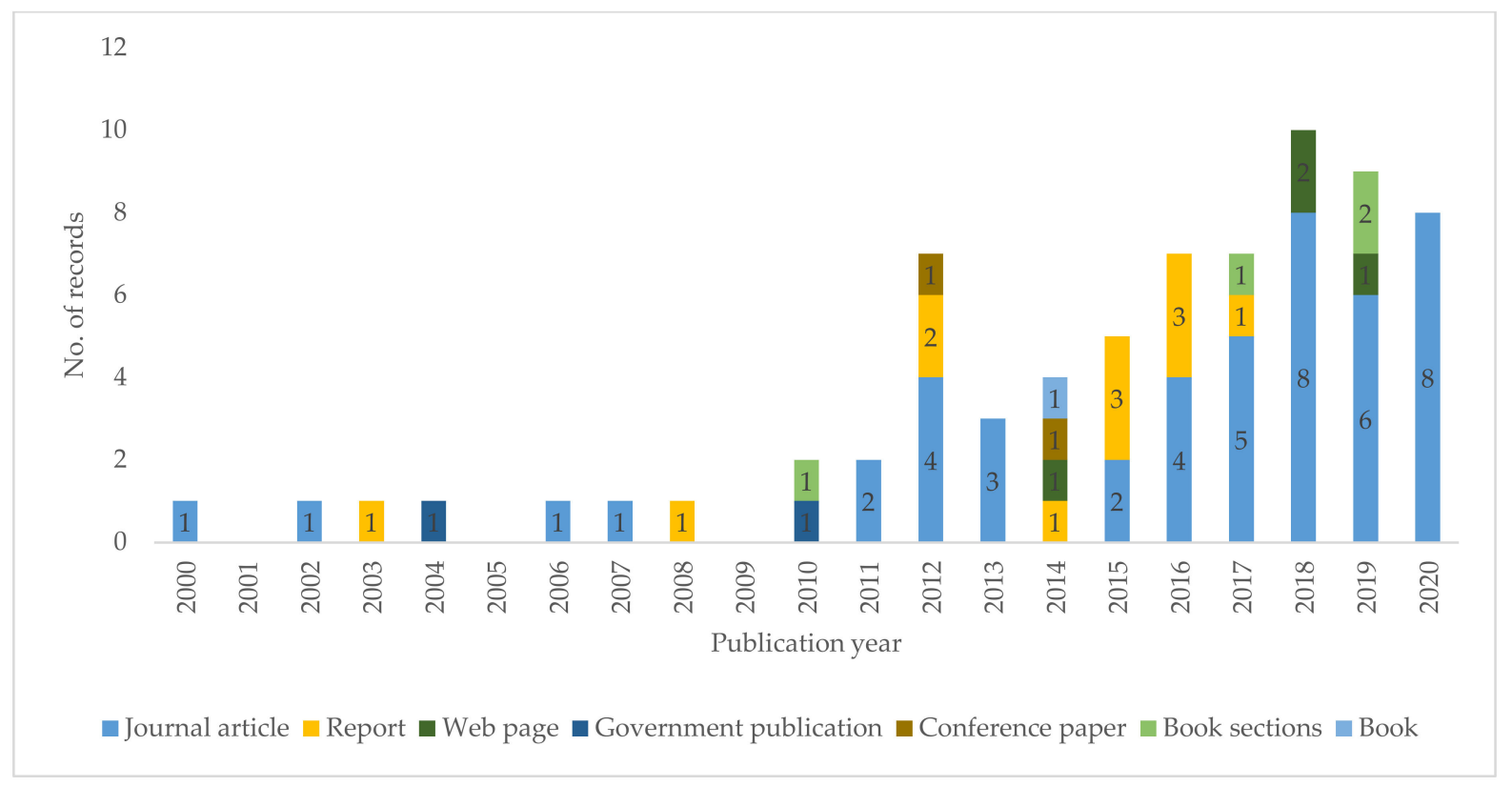

(a)

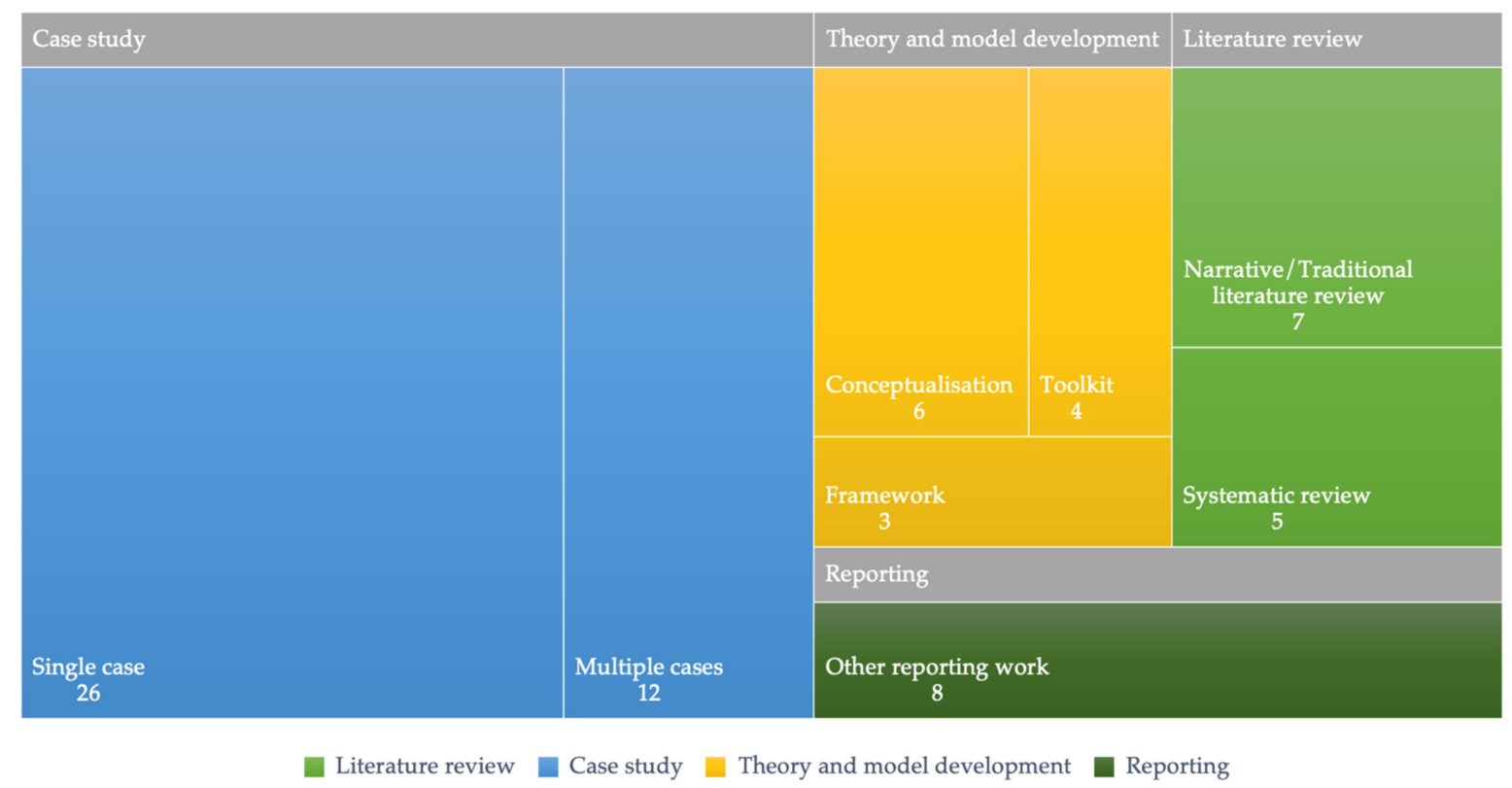

(b)

Figure 3. Classification of the reviewed reports: (a) based on the document type and the publication year, (b) based on the study type (source: the authors).

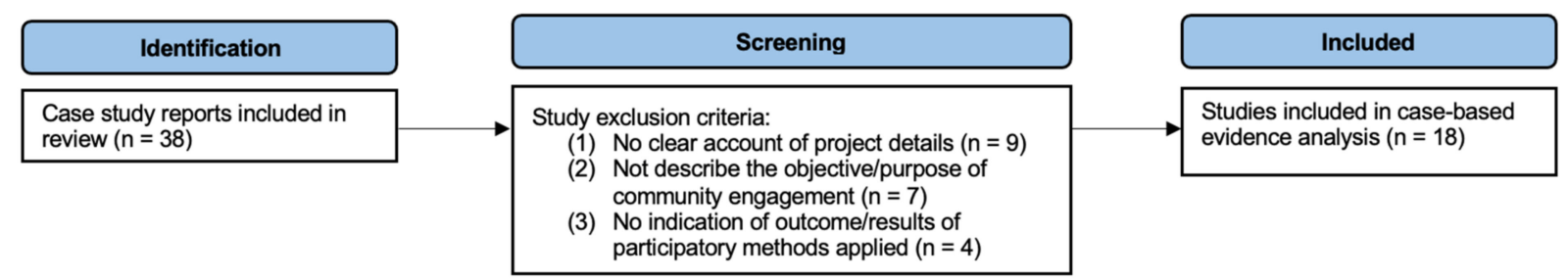

Figure 4. Case study report selection criteria (source: the authors). 


\section{Nexus of Community Engagement with the Urban Development Process}

Community engagement is a "purposeful process which develops a working relationship between communities, community organisations and public and private bodies to help them to identify and act on community needs and ambitions" [18] (as cited in the Scottish Community Development Centre, 2015). Academic researchers from diverse disciplines have produced different models for community engagement in order to widen the public and private sectors' understanding of public participation. In 1969, Arnstein devised a ladder of citizen participation based on the distribution of power between governments and citizens [26]. The ladder consists of eight rungs under three levels of public participation: (1) the first two rungs, namely manipulation and therapy, represent nonparticipation or no power; (2) the next three rungs of informing, consultation and placation represent tokenism; (3) the last three rungs of partnership, delegated power and citizen control represent citizen power. Later, Glass [27] defined five stages of public participation in the form of objectives to be achieved in successful community engagement activity. These are information exchange, education, support building, supplemental decision-making and representational input. As mentioned in [28], the Sunderland Community Development Plan (2008) identified another way of thinking about different levels of involvement, namely: consultation (being informed, consultation, being asked); engagement (commenting on decisions, engagement for developing solutions); and partnership (delivering services).

In 2000, the International Association for Public Participation (IAP2) coined the spectrum of community engagement, which has been modified by researchers over the years but which still remains the most up-to-date and valid model for public participation. This framework consists of five levels of citizen engagement: (1) inform; (2) consult; (3) involve; (4) collaborate; and (5) empower, or citizen-led decision-making [29]. Each of these engagement levels has its purpose. Thus, the implementation of all of these degrees of engagement within a single development project is not recommended anywhere, as each of these levels has a unique role in community engagement that needs to be carefully chosen depending on the project requirements and the context.

Depending on the community groups and representatives involved in the planning phases, different involvement models can be distinguished. Accordingly, [26] (as cited in Sturm, 2013) presents a hierarchy of intensity of participation, ranging from the dissemination of information to interaction and real decision-making, particularly for urban mobility planning. The above discussion on the theoretical transformation of the community engagement concept is summarised in Figure 5.

\begin{tabular}{|c|c|c|c|c|c|c|c|c|}
\hline $\begin{array}{l}\text { Ladder of citizen } \\
\text { participation } \\
\text { (Arnstein, 1969) }\end{array}$ & MANUPULATION & THERAPY & INFORMING & CONSULTATION & PLACATION & PARTNERSHIP & $\begin{array}{l}\text { DELEGATED } \\
\text { POWER }\end{array}$ & $\begin{array}{r}\text { CITIZEN } \\
\text { CONTROL }\end{array}$ \\
\hline $\begin{array}{l}\text { Objectives of public } \\
\text { participation } \\
\text { (Glass, 1979) }\end{array}$ & & & \multicolumn{2}{|c|}{ INFORMATION EXCHANGE } & EDUCATION & $\begin{array}{l}\text { SUPPORT } \\
\text { BUILDING }\end{array}$ & \multicolumn{2}{|c|}{$\begin{array}{l}\text { SUPPLIMENTAL DECISION- } \\
\text { MAKING AND } \\
\text { REPRESENTATIONAL INPUT }\end{array}$} \\
\hline $\begin{array}{l}\text { Spectrum of comn } \\
\text { engagement (IAP2, } \\
2000,2007,2014 \text {, }\end{array}$ & $\begin{array}{l}\text { unity } \\
1990, \\
2018)\end{array}$ & & INFORM & CONSULT & INVOLVE & COLLABORATE & \multicolumn{2}{|c|}{ EMPOWER } \\
\hline \multirow{2}{*}{\multicolumn{3}{|c|}{$\begin{array}{l}\text { Hierarchy of intensity } \\
\text { of participation } \\
\text { (Sturm, 2013) }\end{array}$}} & \multirow{2}{*}{ INFORMATION } & \multirow{2}{*}{ CONSULTATION } & INFLUENCE & \multirow{2}{*}{ CO-DECISION } & \multirow{2}{*}{\multicolumn{2}{|c|}{ DECISION }} \\
\hline & & & & & DIALOG(OPEN) & & & \\
\hline
\end{tabular}

Figure 5. Development of the community engagement concept over the last five decades (source: the authors).

Going beyond the public participation goals defined by the IAP2 [29], the authors of this study posit distinct purposes for which community engagement is demanded in risk-sensitive urban development. The reports relating to all 38 case studies were analysed in order to identify the purpose(s) of community participation. These include the 12 purposes of engagement: the presentation and dissemination of information; public awareness; field observations; opinion collection from a selected group of the general 
public; opinion collection from a large body of the general public; the dissemination of information and building conversations; mapping ideas; creating solutions; gathering expertise and scientific knowledge; bringing deliberation and public participation into public policy decisions; participatory asset management; and participatory monitoring and evaluation. Figure 6, below, shows the classification of these purposes of public participation into the spectrum of community engagement.

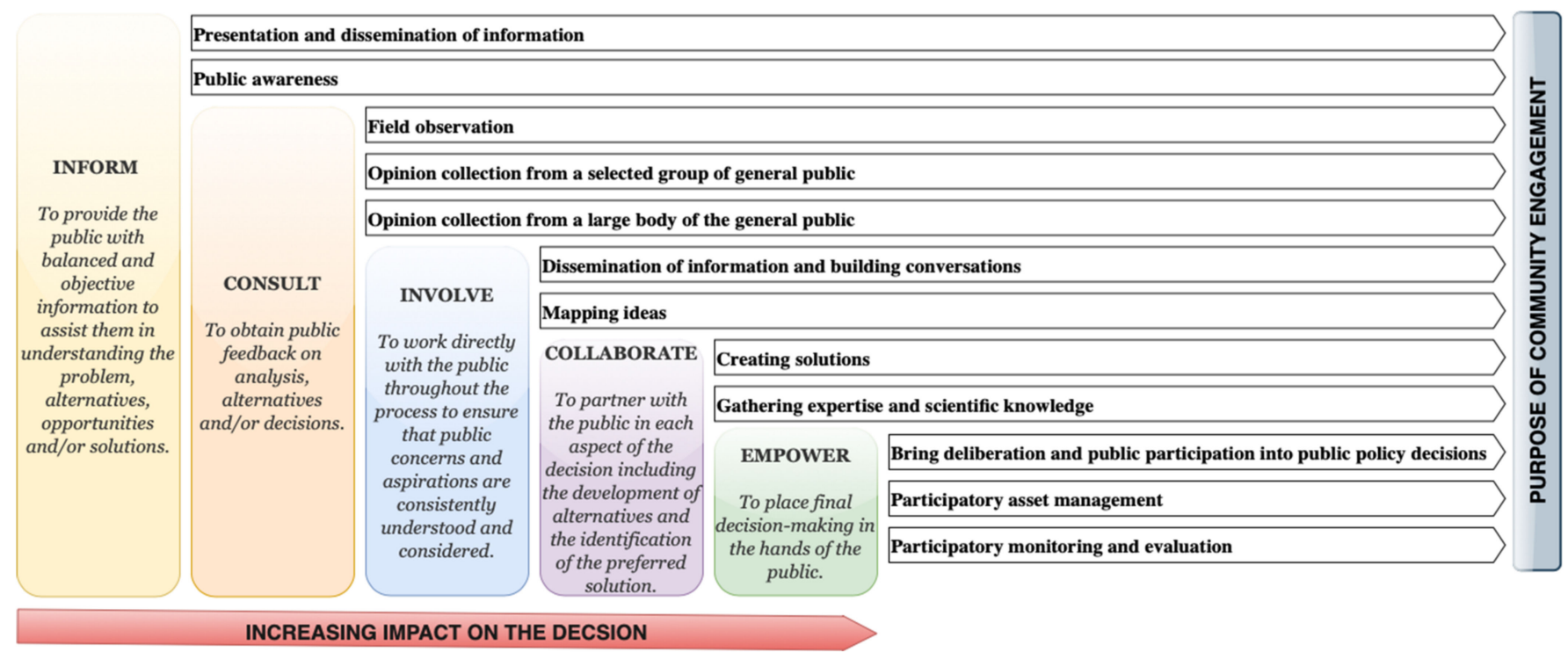

Figure 6. Purpose(s) of community engagement in each level of public participation, as defined by the IAP2's spectrum of community engagement (source: the authors).

\section{Application of Participatory Methods to Achieve Varying Purposes of Public Engagement}

Over the years, many researchers have investigated numerous methods to involve the public in decision-making processes, but these attempts have been constrained by many barriers and challenges, including low community capacities, agencies' silo processes, a lack of a participatory attitude in both the public and practitioners, and ill-defined processes [18]. However, periodically, these methods have been improved for the effective engagement of communities in achieving different purposes of community inclusion and representation.

\subsection{Systematic Review of Community Engagement Methods}

The structured and comprehensive literature review carried out enabled the identification of 34 methods available for community engagement. Table 2, below, presents a summary of these identified methods along with examples of their tools, strengths and associated limitations. As shown in Table 2, the methods reviewed were gathered under the 12 purposes presented in Figure 6, for which community engagement is required in urban development.

This review identified specific tools for the initiation of each participatory method. Although it is highly recommended to use physical engagement tools, there may be situations where it is advisable to use remote engagement tools (e.g., the Covid-19 pandemic, where social distancing is advised). Each tool identified under each participatory method may have different techniques of implementation. For example, if focus groups are chosen to gather data from selected individuals, they may conduct discussions via face-to-face meetings or using remote meeting tools. Thus, the procedure to be used to conduct the discussions may vary based on the tool selected. 
Table 2. Classification of participatory methods into different community engagement purposes in urban development (source: the authors).

\begin{tabular}{|c|c|c|c|c|}
\hline Participatory Method & Examples of Tools & Strengths & Limitations & Sources \\
\hline \multicolumn{5}{|c|}{ Presentation and dissemination of information } \\
\hline Printed material & $\begin{array}{ll}\text { - } & \text { Newsletters } \\
: & \text { Letters } \\
: & \text { Posters } \\
\text { - } & \text { Fact Sheets } \\
\text { - } & \text { Brochures } \\
\text { Reports }\end{array}$ & $\begin{array}{ll}-\quad & \text { Easy to use } \\
-\quad & \text { Less cost }\end{array}$ & $\begin{array}{l}\text { - A traditional method, hence, does not } \\
\text { reach the younger generation }\end{array}$ & {$[30-35]$} \\
\hline $\begin{array}{l}\text { Advertising, Media } \\
\text { coverage }\end{array}$ & $\begin{array}{l}\text { - Paid advertisements on radio, newspapers, } \\
\text { TV or online } \\
\text { Free media (press releases, news } \\
\text { conferences, media packages or letters to } \\
\text { the editor) }\end{array}$ & $\begin{array}{l}\text { - Can be readily accessible by a wider } \\
\text { community }\end{array}$ & $\begin{array}{l}\text { - Tend to attract elite audiences, people } \\
\text { who already have identified their needs } \\
\text { or have a special interest } \\
\text { - } \quad \text { Often very costly } \\
\text { High level of competition for audience } \\
\text { attention }\end{array}$ & {$[31,33,34,36,37]$} \\
\hline Displays/Exhibits & $\begin{array}{l}\text { - Set up at relevant public locations (e.g., } \\
\text { libraries, ward or electorate offices, } \\
\text { shopping centres, community festivals, etc.) }\end{array}$ & $\begin{array}{l}\text { Provides project information and raises } \\
\text { awareness about particular issues } \\
\text { - Can be personalised and interactive } \\
\text { - Can be readily accessible }\end{array}$ & $\begin{array}{l}\text { - } \quad \text { Brief attention spans } \\
\text { - } \quad \text { bimited amount of information that can } \\
\text { - Compeyed } \\
\quad \text { Comition for attention at events }\end{array}$ & {$[30-33]$} \\
\hline $\begin{array}{l}\text { Presentations, Live } \\
\text { streaming, Videos }\end{array}$ & $\begin{array}{ll}\text { - } & \text { PowerPoint } \\
\text { - } & \text { Visme } \\
\text { - } & \text { Caiku Deck } \\
\text { - } & \text { YouTube Live }\end{array}$ & $\begin{array}{l}\text { A creative and attractive way of engaging } \\
\text { people } \\
\text { A great tool to convey messages quickly and } \\
\text { succinctly }\end{array}$ & $\begin{array}{l}\text { - Need creative knowledge and skill in } \\
\text { designing } \\
\text { - Need specific software in designing }\end{array}$ & {$[31-33]$} \\
\hline Website & $\begin{array}{ll}\text { - } & \text { Fact sheets } \\
\text { - } & \text { Downloadable resources } \\
\text { - } & \text { Rhoto galleries } \\
\text { - } & \text { Information forms } \\
& \end{array}$ & $\begin{array}{l}\text { - } \quad \text { Relatively simple and easy to produce } \\
\text { Some can be made more interactive than } \\
\text { conventionally published material } \\
\text { - Capable of reaching a large audience at a low } \\
\text { cost } \\
\text { - Popular information resource }\end{array}$ & $\begin{array}{ll}\text { - } & \text { Not personalised } \\
\text { - } & \text { Require computer literacy and skills } \\
\text { - } & \text { Technical difficulties disadvantaged } \\
& \text { Hard to navigate }\end{array}$ & {$[30-34,36,38-40]$} \\
\hline Infographics & $\begin{array}{l}\text { Hand drawn visual image such as a chart } \\
\text { or diagram used to represent information } \\
\text { or data } \\
\text { Image drawn using a software }\end{array}$ & $\begin{array}{l}\text { - A great tool to simplify complicated or complex } \\
\text { information } \\
\text { - Fun and easy way to learn about a topic or } \\
\text { issue without heavy reading } \\
\text { - Useful for documenting progress and reporting } \\
\text { back during the engagement process }\end{array}$ & $\begin{array}{l}\text { - } \quad \text { Need creative knowledge in design } \\
\text { - Need specific software in designing }\end{array}$ & {$[31,36]$} \\
\hline
\end{tabular}


Table 2. Cont.

\begin{tabular}{|c|c|c|c|c|}
\hline Participatory Method & Examples of Tools & Strengths & Limitations & Sources \\
\hline \multicolumn{5}{|c|}{ Dissemination of information and building conversations } \\
\hline Social media & $\begin{array}{ll}- & \text { Facebook } \\
- & \text { Twitter } \\
- & \text { LinkedIn } \\
- & \text { Instagram } \\
- & \text { Snapchat } \\
- & \text { Pinterest } \\
- & \text { Online forums }\end{array}$ & $\begin{array}{l}\text { - Useful for generating interest and feedback } \\
\text { from the public over some time } \\
\text { Accessible at any time } \\
\text { - The forum can be open to anyone and can be } \\
\text { anonymous, or only to members who sign up } \\
\text { with a special username } \\
\text { - Facilitates public networking } \\
\text { Low cost }\end{array}$ & - $\quad$ Need access to digital devices & {$[31,33,34,36,37]$} \\
\hline \multicolumn{5}{|c|}{ Field observations } \\
\hline Site visits/Tours & $\begin{array}{l}\text { Opening up a project venue for the public } \\
\text { to visit } \\
\text { Optional tours associated with a conference } \\
\text { or workshop }\end{array}$ & $\begin{array}{l}\text { A theoretical or abstract discussion can be } \\
\text { brought into focus by seeing direct evidence } \\
\text { that is available in the field or at a specific } \\
\text { location }\end{array}$ & - $\quad$ Expensive planning & {$[31,41]$} \\
\hline \multicolumn{5}{|c|}{ Public awareness } \\
\hline Public meetings & $\begin{array}{ll}\text { - } & \text { Presentation followed by questions and } \\
\text { answers } \\
\text { - } \quad \text { Town-hall meeting } \\
\text { - } \quad \text { Panel/roundtable } \\
\quad \text { Large group/small group }\end{array}$ & $\begin{array}{l}\text { - Relatively easy to convene, familiar procedures } \\
\text { can involve a wide range of stakeholders } \\
\text { Provides an opportunity to relay information, } \\
\text { explain processes and gather feedback with a } \\
\text { large group of people }\end{array}$ & $\begin{array}{l}\text { Discourages those not used to speaking } \\
\text { in larger groups } \\
\text { - } \quad \text { Can be difficult to control } \\
\text { The audience is not likely to be } \\
\text { representative } \\
\text { Attendance levels can be low unless } \\
\text { people feel deeply connected to the issue } \\
\text { and/or make the time to attend } \\
\text { Ensure the meeting place is accessible }\end{array}$ & {$[30,42]$} \\
\hline \multicolumn{5}{|c|}{ Opinion collection from a selected group of general public } \\
\hline Interviews & $\begin{array}{ll}\text { - } & \text { Face to face } \\
\text { - } & \text { Using virtual tools such as Microsoft } \\
\text { Teams, Zoom, Skype } \\
\text { - Telephone }\end{array}$ & $\begin{array}{l}\text { - Generate in-depth information on a specific } \\
\text { topic }\end{array}$ & $\begin{array}{ll}- & \text { Time-consuming } \\
& \text { Should continue until a data saturation } \\
\text { point is reached }\end{array}$ & {$[17,30-33,39,42-47]$} \\
\hline Focus groups & $\begin{array}{l}\text { - Face to face } \\
\text { Virtual tools: Microsoft Teams, Zoom, } \\
\text { Skype, Mural }\end{array}$ & $\begin{array}{l}\text { Can explore different perspectives of a small } \\
\text { group of people of a common issue/goal }\end{array}$ & $\begin{array}{l}\text { - Not effective for providing information } \\
\text { to the public }\end{array}$ & {$[30-33,41,47]$} \\
\hline
\end{tabular}


Table 2. Cont.

\begin{tabular}{|c|c|c|c|c|}
\hline Participatory Method & Examples of Tools & Strengths & Limitations & Sources \\
\hline \multicolumn{5}{|c|}{ Opinion collection from a large body of the general public } \\
\hline Polls & $\begin{array}{ll}\text { - } & \text { Physical polling booths } \\
\text { - } & \text { Postal vote } \\
& \text { Online vote (SmartSurvey) }\end{array}$ & $\begin{array}{l}\text { - Are a highly representative nature } \\
\text { Using scientifically developed techniques, } \\
\text { samples from polls generate an accurate match } \\
\text { of the population } \\
\text { - Allow issue specificity with immediate } \\
\text { feedback }\end{array}$ & $\begin{array}{l}\text { - Measure an immediate response to a } \\
\text { question, thereby granting little } \\
\text { opportunity for informed opinions or } \\
\text { discussion of issues } \\
\text { Polling information is meaningless if it is } \\
\text { not statistically valid }\end{array}$ & {$[30-33,36]$} \\
\hline Surveys & $\begin{array}{ll} & \\
\bullet \quad & \text { Paper survey } \\
\text { - } \quad \text { Postal survey } \\
\quad \text { Onail survey } \\
\quad \text { SurveyMonkey) }\end{array}$ & $\begin{array}{l}\text { - Find out the opinions of local people on a } \\
\text { particular topic in a structured way that can be } \\
\text { extensively analysed } \\
\text { Provide a baseline for measuring changes in } \\
\text { people's views } \\
\text { - Inform people about the project that is taking } \\
\text { place } \\
\text { Prompt further involvement by asking if people } \\
\text { would like to receive information or invitations } \\
\text { to future events } \\
\text { Reach a large group of people and involve } \\
\text { those who may not be in a position to engage in } \\
\text { other ways }\end{array}$ & $\begin{array}{l}\text { - } \quad \text { Time-consuming process } \\
\text { Results may be statistically incorrect if a } \\
\text { large sample is not involved }\end{array}$ & {$[17,30-33,35,39,42-46]$} \\
\hline \multicolumn{5}{|c|}{ Gathering expertise and scientific knowledge } \\
\hline $\begin{array}{l}\text { Expert panels, Working } \\
\text { groups }\end{array}$ & $\begin{array}{ll}- & \text { Round tables } \\
- & \text { GoToMeeting } \\
\text { - } & \text { Slack } \\
\text { - } & \text { WebEx } \\
\text { - } & \text { Igloo }\end{array}$ & $\begin{array}{l}\text { - Suitable when highly specialised input and } \\
\text { opinion are required for a project } \\
\text { Allow citizens to hear a variety of informed } \\
\text { (expert) viewpoints from which to decide on } \\
\text { recommendations or courses of action about an } \\
\text { issue or proposal }\end{array}$ & - Expensive in recruiting experts & {$[31,32,41]$} \\
\hline
\end{tabular}


Table 2. Cont.

\begin{tabular}{|c|c|c|c|c|}
\hline Participatory Method & Examples of Tools & Strengths & Limitations & Sources \\
\hline \multicolumn{5}{|c|}{ Mapping ideas } \\
\hline System dynamics (SD) & $\begin{array}{ll}- & \text { Group model building (GMB) } \\
\text { - } & \text { Participatory SD modelling } \\
& \text { Community-based SD }\end{array}$ & $\begin{array}{l}\text { - Allows researchers and relevant stakeholders to } \\
\text { come together and, in a participatory manner, } \\
\text { elaborate conceptual models of system } \\
\text { behaviours/problems } \\
\text { Effective tool to elicit a common vision on a } \\
\text { complex problem }\end{array}$ & $\begin{array}{l}\text { - Complex and need advanced knowledge } \\
\text { in the application }\end{array}$ & {$[37,38,42,49-52]$} \\
\hline $\begin{array}{c}\text { Community } \\
\text { mapping/Mind mapping }\end{array}$ & $\begin{array}{ll}\text { - } & \text { Round tables } \\
\text { - } & \text { Public participatory geographic } \\
\text { information system (PPGIS) } \\
\text { - } \quad \text { Virtual mapping tools (Mapping for } \\
\text { Change CIC) }\end{array}$ & $\begin{array}{l}\text { - Enable citizens to map the social, ecological and } \\
\text { economic assets, along with historical events of } \\
\text { their community } \\
\text { A useful way for initiating dialogue and } \\
\text { planning in a community } \\
\text { The method can be used to document certain } \\
\text { aspects, strengths or weaknesses, or locations of } \\
\text { services within a community, neighbourhood, } \\
\text { or municipality }\end{array}$ & $\begin{array}{ll}- & \text { Time-consuming } \\
\text { - } & \text { Expensive in process }\end{array}$ & {$[31,53,54]$} \\
\hline \multicolumn{5}{|c|}{ Bring deliberation and public participation into public policy decisions } \\
\hline Citizen juries & $\begin{array}{ll}- & \text { Round tables } \\
\text { - } & \text { Virtual meeting tools }\end{array}$ & $\begin{array}{l}\text { - } \quad \text { Bring new thinking to the issue at hand } \\
\text { - } \quad \text { Hevelop a deep understanding of an issue } \\
\text { involvement and increased knowledge } \\
\text { - } \quad \text { Limitations and possibilities can be identified } \\
\text { - } \quad \text { Can dispel misinformation } \\
\quad \text { benefits }\end{array}$ & $\begin{array}{l}\text { - } \quad \text { Group selection can be mistrusted } \\
\text { - } \quad \text { Participants may not show up on the day } \\
\text { - } \quad \text { The cost can be extensive } \\
\text { - } \quad \text { The same-consuming for all involved } \\
\quad \text { The sample of the community is small }\end{array}$ & {$[31-33,41]$} \\
\hline Citizen committees & $\begin{array}{ll}\text { - } & \text { Physical gathering } \\
\text { - } & \text { Virtual meeting tools }\end{array}$ & $\begin{array}{l}\text { - The committee can offer specialised, practical } \\
\text { expertise that may not be available from other } \\
\text { sources such as government authorities } \\
\text { Can lend legitimacy and credibility to the } \\
\text { ultimate decision made by a government }\end{array}$ & $\begin{array}{l}\text { - No clear formal mechanism to input into } \\
\text { the decision-making process } \\
\text { - Need to offer sufficient time for members } \\
\text { to commit to the process } \\
\text { - Timeframes are unrealistic } \\
\text { - Agenda too ambitious or not specific } \\
\text { enough }\end{array}$ & {$[31,35]$} \\
\hline Visioning & $\begin{array}{ll}\text { - } & \text { Facilitated idea-sharing and recording } \\
\text { - } & \text { Gotecard/flip chart brainstorming } \\
& \text { Graphic facilitation (e.g., PATHTM) }\end{array}$ & $\begin{array}{l}\text { Brings citizens and stakeholders together to } \\
\text { assist a group of stakeholders in developing a } \\
\text { shared vision of the future }\end{array}$ & $\begin{array}{l}\text { - Require long-term commitment } \\
\text { It may be challenging to give a healthy } \\
\text { balance of attention to each of the areas } \\
\text { determined to be important in the } \\
\text { community }\end{array}$ & {$[26,30-32]$} \\
\hline
\end{tabular}


Table 2. Cont.

\begin{tabular}{|c|c|c|c|c|}
\hline Participatory Method & Examples of Tools & Strengths & Limitations & Sources \\
\hline \multicolumn{5}{|c|}{ Bring deliberation and public participation into public policy decisions } \\
\hline $\begin{array}{l}\text { Community indicator } \\
\text { projects }\end{array}$ & $\begin{array}{l}\text { - Community Indicators' Consortium } \\
\text { toolbox }\end{array}$ & $\begin{array}{l}\text { - Offer the opportunity to discuss what is } \\
\text { important, systematically review whether } \\
\text { things have been getting better or worse, and } \\
\text { establish priorities for policy response } \\
\text { Indicators measure what the community cares } \\
\text { about and track whether the community is } \\
\text { moving in the right direction } \\
\text { These metrics provide essential guidance for } \\
\text { action and key tools for appropriate } \\
\text { engagement of the public }\end{array}$ & - $\quad$ Require long-term commitment & [31] \\
\hline \multicolumn{5}{|c|}{ Creating solutions } \\
\hline $\begin{array}{l}\text { Workshop, Open space } \\
\text { events }\end{array}$ & $\begin{array}{l}\text { - } \quad \text { Physical workshops } \\
\text { Remote workshops using Mentimeter, } \\
\text { Slido, Go Create }\end{array}$ & $\begin{array}{l}\text { - Help to translate detailed discussions into } \\
\text { action plans } \\
\text { Provide an opportunity to bring together the } \\
\text { knowledge of all participants and is attractive } \\
\text { because they set the workshop agendas }\end{array}$ & $\begin{array}{l}\text { Participants attending may have very } \\
\text { disparate skills and knowledge } \\
\text { Logistics-It can be difficult to arrange } \\
\text { meetings and workshops for different } \\
\text { geographical locations and time zones }\end{array}$ & {$[30-32,34,35,41,47,55]$} \\
\hline $\begin{array}{l}\text { Design charrette, } \\
\text { Tactic-urbanism } \\
\text { (Placemaking, Pop-ups) }\end{array}$ & $\begin{array}{l}\text { - Physical gathering } \\
\text { Digital tools such as SketchUp, Dynamo, } \\
\text { Grasshopper }\end{array}$ & $\begin{array}{l}\text { Provide a forum for ideas and offers the unique } \\
\text { advantage of giving immediate feedback to the } \\
\text { designers }\end{array}$ & $\begin{array}{l}\text { - With multiple perspectives represented } \\
\text { in the charrette, it is challenging and } \\
\text { time-consuming for all involved to agree } \\
\text { on the final design solution } \\
\text { - Experts may dominate it }\end{array}$ & [31] \\
\hline $\begin{array}{l}\text { Knowledge/document } \\
\text { co-creation }\end{array}$ & - Open Innovation Digital Platforms & $\begin{array}{l}\text { - Allow for the collection of indigenous wisdom } \\
\text { and creating design solutions with social } \\
\text { empathy and inclusion }\end{array}$ & $\begin{array}{l}\text { - High dependence on communities' } \\
\text { views/interests }\end{array}$ & {$[38,50,55-57]$} \\
\hline
\end{tabular}


Table 2. Cont.

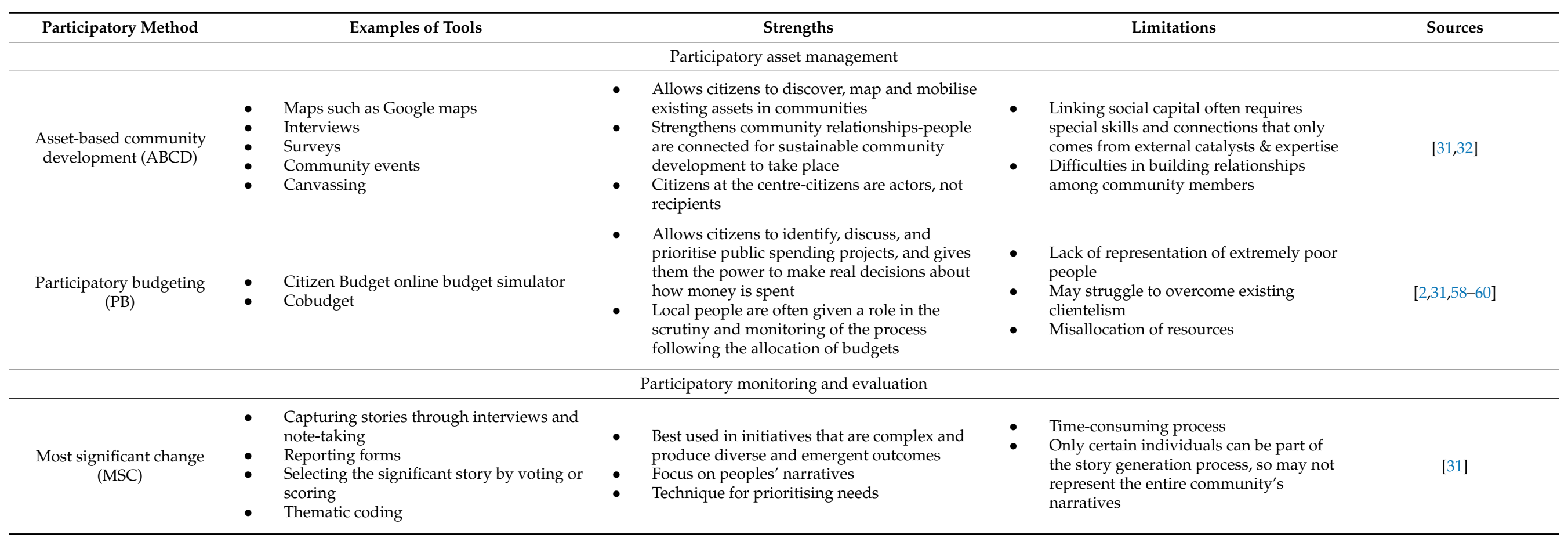


However, each of these participatory methods offers different degrees of community engagement. Therefore, the next section presents a mapping of these methods within the five phases of the community engagement spectrum.

\subsection{Mapping of Participatory Methods into the Spectrum of Community Engagement}

Based on the characteristics of each method and the purpose of their application, these methods were classified within the spectrum of community engagement in order to better understand which participatory methods are more appropriate in each phase of participation. Figure 7, below, illustrates the mapping of the existing participatory methods into the community engagement spectrum.

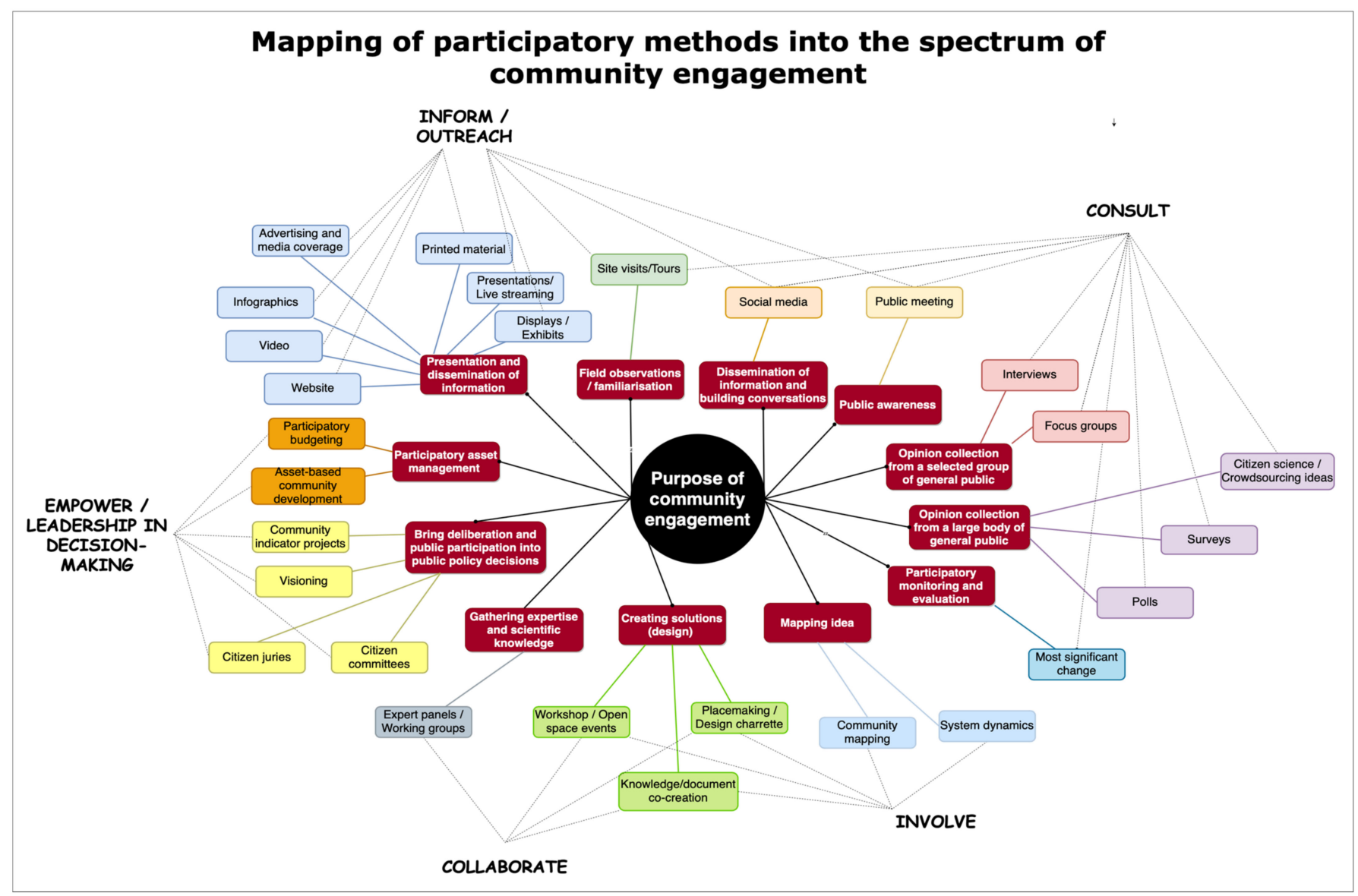

Figure 7. Mapping of participatory methods into the spectrum of community engagement (source: the authors).

The 'inform' level of public participation does not provide the opportunity for public participation at all, but provides the public with the information they need to understand the decisions made by agencies [29]. However, the inform level reminds project implementors and decision-making agencies that they should serve as honest brokers of information. At this level, they should at the least give the public what they need to fully understand the project and decision(s), and to reach their conclusions as to the appropriateness and adequacy of the decision(s). The presentation and dissemination at the inform level are achieved through simple methods such as printed materials, websites, videos, infographics, advertising via media, presentations/live streaming and displays/model exhibits. These methods provide one-way communication through which practitioners can educate communities on upcoming developments.

As these methods do not serve as an opportunity to build a valid conversation with, or to receive feedback from, communities, satisfactory and meaningful information facilitation can be provided through social media platforms, which are a promissory method of 
engaging youth. In addition, public meetings can be used to inform larger groups of people and generate inter-community discussions about prospective development. The rise of social media also revives old questions on how decision-making processes can achieve a balance between representative, delegable, participative and direct democracy [31]. The Organisation for Economic Co-Operation and Development (OECD) [36] has pronounced that the use of social media platforms has already been used not only to inform but also to consult. Similarly, public meetings also encourage two-way communication, as this method generally has a facilitator for community questions and a recorder who records suggestions and issues that are revealed at the meeting [31]. In a case where it requires a particular community to understand the nature of a development site (such as the construction of an industrial or commercial facility), to avoid a possible public protest, practitioners can arrange a site visit(s) to the development location, as this allows locals to better understand the project details. Although informing the public via social media platforms, public meetings and site visits offers some level of public consultation about prospective development, there is no guarantee that their voices will be integrated into the decision-making process.

The 'consult' level of public participation provides the basic minimum opportunity for bringing public input into a decision. In terms of development, consultation is particularly appropriate when there is little complexity in an issue, and it can be useful for obtaining feedback about a draft plan or for canvassing a range of views early on in a longer planning process (although not necessarily acting on them). Consultation with little interaction can be achieved through surveys, interviews and polls. A survey or an interview helps to understand the opinions of stakeholders on a particular topic in a structured way which can be extensively analysed. Polls, as a voting method, allow people to register their opinion and thus to quickly provide an assessment of a current situation [30]. A simple vote on an urban development plan will give the respective authorities an idea of the level of local awareness and support for an issue, and can open up the way for other engagement strategies.

Consultation can be more interactive when it uses methods such as focus groups, citizen science or crowdsourcing. Focus groups are small group discussions that generate in-depth information on a specific topic. Citizen science facilitates the collection of data in an organised way from the members of the public, typically in collaboration with professional scientists [48]. Crowdsourcing, on the other hand, offers a method to bring in people who are interested in an issue and actively engage them longitudinally until a sound solution is reached [31].

In terms of quantity, surveys, polls and citizen science or crowdsourcing methods have shown potential in approaching a larger group of the public. In contrast, individual interviews and focus groups are much more effective for obtaining opinions about a particular development from a selective community, such as prospective inhabitants or local representatives who live in proximity to that development. The Most Significant Change (MSC) is a form of participatory monitoring and evaluation. It involves many project stakeholders both in deciding the sorts of changes to be recorded and in analysing the data collected [31]. Furthermore, it is a form of monitoring because it occurs throughout the programme cycle and provides information to help people manage the programme. It contributes to evaluation because it provides data on the impact and outcomes that can be used to help assess the performance of the programme as a whole. Though these methods keep the promise of the consult level to 'listen and acknowledge public feedback', it is questionable whether these consultation methods facilitate two-way communication. Nevertheless, this stage of community participation allows agencies to identify potential issues that need to be considered in order to guide the next stages of the development planning with the active involvement of the community.

At the 'involve' level, the public is invited into the decision-making process, typically from the beginning, and are offered multiple ongoing opportunities to provide input into the decision-making process as the development solutions mature over time. However, the 
respective agencies are still the decision-makers, and there is no expectation of building consensus or offering the public any sort of high-level influence over the decision [29]. This approach typically considers both community requirements and perspectives with government requirements in order to generate alternative design proposals. In this approach, there is a need to update communities throughout a development process until the final design is reached.

The involve level participatory approach interactively engages the community to understand community requirements and to explore design ideas using idea mapping and co-creation tools. Community mapping and system dynamics (SD) are specialised methods for mapping different perspectives. Community mapping, sometimes known as asset mapping, is the process and product of a community getting together to map its own assets, values, beliefs, or any other self-selected attributes. A community map highlights people, physical structures, organisations and institutions that can be used to create a meaningful service project for the community. SD is a promissory public involvement method that uses simulation modelling (causal loop diagrams) to capture the views and ideas of the stakeholders [61]. It is suitable for studying complex systems. Király and Miskolczi [62] identified three main approaches to participatory SD modelling: (1) group model building (GMB); (2) participatory SD modelling for policymaking; and (3) community-based $\mathrm{SD}$. These three methods differ significantly in terms of the category of stakeholders to be involved, the facilitating techniques and the key expected outcomes [51]. The GMB approach involves executives, entrepreneurs and/or professionals in a corporate context, and recommends facilitation techniques that do not overload the clients while keeping the model simple and understandable. The key expected outcomes from the GMB approach are participant ownership, social capital, commitment to change and the prioritisation of model-consistent decisions [63]. Participatory SD modelling for policymaking involves people from non-governmental organisations (NGOs) and/or government agencies, and recommends facilitation techniques that maximise participation in the initial phase of problem setting and the final phase of simulation testing. The simulation building process that happens during these two phases is left to expert modellers. The key expected outcomes of the participatory SD approach are system predictability, model-consistent decisions, and social capital [64]. Community-based SD, on the other hand, involves the whole community (especially marginalised members), recommends facilitation techniques that are based on social counselling, and prioritises participants' social capital and empowerment as the key expected outcomes [65]. However, the complexity of SD models makes it difficult for users to understand the details of the models $[61,64]$.

Other methods that are being used to involve communities are workshops, design charette, placemaking and knowledge co-creation workshops, which not only involve communities but also facilitate collaboration to a certain degree.

The 'collaborate' level in the engagement spectrum aims to partner with the public in each aspect of a decision, including the development of alternatives and the identification of the preferred solution. The collaboration level promises to incorporate advice and recommendations from the public to the maximum extent possible, but decision-making still lies with the development-related organisations. As mentioned above, workshops or open-space events, design charettes and knowledge co-creation methods provide an interactive course of action with an emphasis on two-way processes in the creation of alternative design solutions. Workshops and open-space events are most useful when bringing together representatives from diverse groups who share a common interest in an issue but bring different perspectives on how it should be addressed [30]. A design charrette and placemaking are methods that are used for intensive planning sessions where citizens, designers and others collaborate on a vision for development, particularly remodelling failing, abandoned or underused spaces to make them more attractive through temporary structures and installations [31]. More importantly, it allows everyone who participates to be a joint author of the plan. Knowledge co-creation leads to the development of novel ways to re-frame a social problem and its solutions, creating messages and new messengers 
that reflect the lived experience of a target population, and providing inroads that open up new possibilities for change [50]. Although it has become a priority for agencies to include methods of co-creation with the community, especially in the planning and post-occupancy phases, the tension between the need to establish future goals and the necessity of allowing physical and cultural flexibility remains in most urban development processes [66].

Collaboration methods such as expert panels and working groups are especially designed for stakeholders to work together towards a common objective while incorporating the scientific knowledge and experience of subject experts and specialised community groups. Experts' opinions and their experience provide useful input into the decisionmaking process, particularly in urban planning and development.

As the foregoing discussion elaborates, the first four levels of the community engagement spectrum range from no participation to interactive participation but do not provide an avenue for community-led decision-making. At the top level of community engagement, the 'empower' level places the final decision-making in the hands of the public. Community leadership in decision-making in urban development is purposeful when there is a need to bring deliberation into policy formation in order to understand and incorporate ground-level data. This can be achieved by implementing participative empowerment methods such as citizen committees, citizen juries, visioning and community indicator projects. Citizen committees (also known as public advisory committees and public liaison committees) consist of a group of representatives from a particular community or a set of interests who are appointed to provide comments and advice on an issue. More importantly, the members meet regularly to provide ongoing input and advice throughout a project [31], thus significantly contributing to the decision-making process. Unlike citizen committees, citizen juries only involve experts on a particular theme and bring expert knowledge and ideas together to build discussions and assist in making informed decisions on a focus area. Visioning is a method typically used in planning, wherein residents are brought in to participate in the creation of urban or landscape visions [31]. Community indicator projects are those where communities have a vision for a sustainable future and have established ways of tracking their progress using indicators. The list of indicators varies, and is generally developed by the community itself [31]. In this approach, indicators are selected either across topical domains or with a focus (e.g., children) in order to collectively track trends in the community's well-being and quality of life [31].

When making development decisions related to available resources, participatory asset management methods can be employed. Asset-Based Community Development $(A B C D)$ is an innovative methodology for assessing the resources, skills and experience available in a community; organising the community around issues that move its members into action; and then determining and taking the appropriate action [31]. It aims to exploit the community's own strengths and potentials to facilitate the sustainable development of the community. This method uses the community's assets and resources as the basis for development; it empowers the people of the community by encouraging them to utilise what they already possess [31,32]. Similarly, participatory budgeting, as a form of citizen participation in which citizens are involved in the process of deciding how public money is spent, is widely being applied in participative financial decision-making. These are innovative policymaking processes that allow citizens to be directly involved in making policy decisions [31].

The foregoing review and the analysis of the review results provide a thorough account of the participatory methods appropriate for each level of community engagement. However, there is little guidance on selecting the appropriate participatory methods for practitioners for the different stages of the urban development process. This gap is addressed in the next section of this article.

\section{Application of Participatory Methods for Inclusive Urban Developments: A Case-Based Evidence Analysis}

The typical urban development processes are based on different plans of work recommended by various construction industry-related organisations and professional bodies 
such as the Royal Institute of British Architects (RIBA) in the UK, the Architects' Council of Europe (ACE), and NATSPEC in Australia. Although each of these plans of work is different, they all have the same goals: to provide the project team with a road map for the promotion of consistency from one stage to the next, and to provide vital guidance to clients undertaking development projects. This study used the following five phases: (1) Predesign analysis (Conceptual design), (2) Briefing, (3) Professional design, (4) Development, and (5) Post-development, which represent the key phases used in the above-mentioned urban development processes, in order to establish the case-based knowledge of community engagement in each phase of development.

Accordingly, this section of the study presents an analysis of the participatory methods used to achieve different levels of community engagement in 18 inclusive development cases. The cases were carefully selected from both developed and emerging economies, and the results are presented in Table 3. 
Table 3. Case-based evidence analysis of the participatory methods used in inclusive development projects (source: the authors).

\begin{tabular}{|c|c|c|c|c|c|c|c|c|c|c|c|c|c|}
\hline \multirow[b]{2}{*}{ UD Project (Country, Year) } & \multirow[b]{2}{*}{ Project Purpose } & \multirow[b]{2}{*}{ Community Engagement Objective(s) } & \multicolumn{5}{|c|}{ Targeted UD Phase(s) } & \multicolumn{5}{|c|}{ Degree of Community Engagement } & \multirow[b]{2}{*}{ Participatory Method(s)/Tool(s) Used } \\
\hline & & & $\begin{array}{c}\text { Pre-Design } \\
\text { Analysis }\end{array}$ & Briefing & $\begin{array}{c}\text { Professional } \\
\text { Design }\end{array}$ & Development & Post-Development & Inform & Consult & Involve & Collaborate & Empower & \\
\hline \multirow[b]{2}{*}{$\begin{array}{l}\text { A. Metro Vancouver } 2040 \\
\text { (Canada, 2010) [59] }\end{array}$} & \multirow[b]{2}{*}{ To develop the regional growth strategy } & $\begin{array}{l}\text { - Foster public understanding of the } \\
\text { purpose of regional planning }\end{array}$ & $x$ & & & & & $\mathrm{x}$ & & & & & $\begin{array}{ll}\text { Weekly blog updates } \\
\text { N Newspaper advertisements } \\
\text { Website with videos }\end{array}$ \\
\hline & & $\begin{array}{l}\text { - } \quad \text { Discuss the key regional policies and } \\
\text { seek public comment }\end{array}$ & & $\mathrm{x}$ & & & & & $\mathrm{x}$ & & & & $\begin{array}{ll} & \text { Public meetings + voting } \\
& \text { Workshop } \\
\text { Regional forums } \\
\text { Wecinar } \\
& \text { Focus groups } \\
\end{array}$ \\
\hline $\begin{array}{l}\text { B. Victoria Square } \\
\text { development (New Zealand, } \\
\text { 2015) [2] }\end{array}$ & $\begin{array}{l}\text { To provide opportunities for the public } \\
\text { to contribute views and ideas for the } \\
\text { future refurbishmment of Victoria Square }\end{array}$ & $\begin{array}{ll}\text { - } & \text { Eliminate public rejection of the city } \\
\text { proposal provided by the city council } \\
\text { A draft city remodelling proposal } \\
\text { based on the feedback }\end{array}$ & $\mathrm{x}$ & & & & & & $\mathrm{x}$ & & & & $\begin{array}{ll}\cdot & \text { A mobilie consultation unit } \\
\text { including initormation panels } \\
\text { Interactive digtial stations } \\
\text { Paper questionnaires }\end{array}$ \\
\hline $\begin{array}{l}\text { C. Future Visioning of } \\
\text { Urban Landscapes (USA) [3] }\end{array}$ & To explore new uses of urban landscapes & $\begin{array}{l}\text { - Sequential refinement and } \\
\text { crystalli-sation of key issues and ideas } \\
\text { within large groups of poople. }\end{array}$ & $\mathrm{x}$ & & & & & & $x$ & & & & - World Café: community tables \\
\hline $\begin{array}{l}\text { D. NextCampus (Germany, } \\
\text { 2012) [67] }\end{array}$ & $\begin{array}{l}\text { Moving campus facility into a new } \\
\text { location }\end{array}$ & $\begin{array}{l}\text { - To find the most satisfactory urban } \\
\text { planning solution for the university } \\
\text { campus. } \\
\text { To educate players (i.e., university staff } \\
\text { and students) about the current saf } \\
\text { situation of the university campus } \\
\text { buildings and the possible } \\
\text { consequences of a variety of actions } \\
\text { measured by money spent or gained. } \\
\text { Players made 3D simulation models of } \\
\text { the campus showcasing their } \\
\text { expectations. }\end{array}$ & $\mathrm{x}$ & & & & & $\mathrm{x}$ & & & & & $\begin{array}{l}\text { - Serious games (online) } \\
\text { including playful elements } \\
\text { such as storytelling, virtual } \\
\text { walking, sketching, drawing, } \\
\text { and gaming }\end{array}$ \\
\hline $\begin{array}{l}\text { E. The Bandar-Abbas City } \\
\text { Informal Settlementsts } \\
\text { Upgrading proiect (BACCU) } \\
\text { (Iran, 2012) [68] }\end{array}$ & $\begin{array}{l}\text { To create safe residential zones, } \\
\text { habitation, onnership rights and } \\
\text { provide access to financial sources for } \\
\text { low-income groups (funded by the } \\
\text { World Bank) }\end{array}$ & $\begin{array}{l}\text { To seek public opinion in the } \\
\text { preparation of the city vision }\end{array}$ & $\mathrm{x}$ & & & & & & $\mathrm{x}$ & & & & $\begin{array}{ll}\text { Focus group } \\
\text { Interviews }\end{array}$ \\
\hline \multirow{2}{*}{$\begin{array}{l}\text { F. Metropolitan } \\
\text { Florianópolis's ambitious } \\
\text { new sustainable mobility } \\
\text { plan (PLAMUS) (Brazil, } \\
\text { 2014) [69] }\end{array}$} & \multirow[b]{2}{*}{$\begin{array}{c}\text { Developing a metropolitan mobility } \\
\text { plan }\end{array}$} & \multirow[b]{2}{*}{$\begin{array}{l}\text { - To include community ideas into the } \\
\text { metropolitan mobility plan }\end{array}$} & $x$ & & & & & & $x$ & & & & Public surveys \\
\hline & & & $\mathrm{x}$ & & & & & & & $\mathrm{x}$ & & & $\begin{array}{ll}\text { Interactive workshops } \\
\text { Online engagement } \\
\text { campaigns }\end{array}$ \\
\hline $\begin{array}{l}\text { G. Building urban flood } \\
\text { resilience (Kenya, 2015) [43] }\end{array}$ & $\begin{array}{l}\text { To develop a flood model integrating } \\
\text { community perspectives }\end{array}$ & $\begin{array}{l}\text { To produce flood depth and extent } \\
\text { maps on a rage of scales to support } \\
\text { stakeholder consultations; overlay of } \\
\text { community data and major and minor } \\
\text { infrastructure planning }\end{array}$ & $\mathrm{x}$ & & & & & & & $\mathrm{x}$ & & & 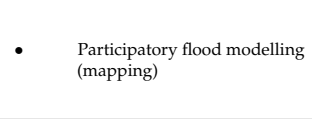 \\
\hline $\begin{array}{l}\text { H. UR[BNE] (Australia, } \\
\text { 2012) [2] }\end{array}$ & $\begin{array}{l}\text { To create greater public involvement } \\
\text { and understandingo f how urban places } \\
\text { are designed, building pride and interest } \\
\text { in Brisbane's slaces, and generally } \\
\text { livening up the city. }\end{array}$ & $\begin{array}{l}\text { - Change people's perception of urban } \\
\text { spaces from that of 'an uninsppiring, } \\
\text { one-dimensional offer' to 'vibrant, } \\
\text { activated destinations'. }\end{array}$ & $\mathrm{x}$ & & & & & & & $\mathrm{x}$ & & & $\begin{array}{l}\text { Open space events-annual } \\
\text { community festival including } \\
\text { music, live art, street picnics, } \\
\text { fashion parades, urban design } \\
\text { film screenings, bike rides, } \\
\text { walking tours and photo hunts }\end{array}$ \\
\hline $\begin{array}{l}\text { I. Maroochydore centre } \\
\text { master planning process } \\
\text { (Australia, 2014) [2] }\end{array}$ & To masterplan the Maroochydore centre & Produce different masterplan options & $\mathrm{x}$ & & & & & & & & $\mathrm{x}$ & & - $\quad \begin{array}{l}\text { City shape models (worked in } \\
\text { small groups) }\end{array}$ \\
\hline
\end{tabular}


Table 3. Cont

\begin{tabular}{|c|c|c|c|c|c|c|c|c|c|c|c|c|c|}
\hline \multirow[b]{2}{*}{ UD Project (Country, Year) } & \multirow[b]{2}{*}{ Project Purpose } & \multirow[b]{2}{*}{ Community Engagement Objective(s) } & \multicolumn{5}{|c|}{ Targeted UD Phase(s) } & \multicolumn{5}{|c|}{ Degree of Community Engagement } & \multirow[b]{2}{*}{ Participatory Method(s)/Tool(s) Used } \\
\hline & & & $\begin{array}{c}\text { Pre-Design } \\
\text { Analysis }\end{array}$ & Briefing & $\begin{array}{c}\text { Professional } \\
\text { Design }\end{array}$ & Development & Post-Development & Inform & Consult & Involve & Collaborate & Empower & \\
\hline $\begin{array}{l}\text { J. The 7th Havana Urban } \\
\text { Design Charrette (Cuba, } \\
\text { 2014) [2] }\end{array}$ & $\begin{array}{l}\text { To developp urban strategies and } \\
\text { proposals for the EI Vedado } \\
\text { neighbourhood of Havana }\end{array}$ & $\begin{array}{ll}\text { - } & \text { To understand strategic urban design } \\
\text { issues related to EI Vedado as a whole } \\
\text { - } & \text { Develop urban strategies and } \\
\text { proposals for specific key sub-areas }\end{array}$ & $\mathrm{x}$ & & & & & & & & $\mathrm{x}$ & & Design Charrette \\
\hline \multirow{2}{*}{$\begin{array}{l}\text { K. Luxor Street in Mansheit } \\
\text { Nasser (Egypt, 2015) [70] }\end{array}$} & \multirow{2}{*}{$\begin{array}{l}\text { Improving the living conditions and } \\
\text { quality of life for people in poor areas, } \\
\text { through restraining the socioeconomic } \\
\text { problems }\end{array}$} & $\begin{array}{l}\text { - To identify the population's key need } \\
\text { to develop a touristic street }\end{array}$ & $\mathrm{x}$ & & & & & & $\mathrm{x}$ & & & & Public survey \\
\hline & & - To shaping the urban space & & $\mathrm{x}$ & & & & & & & $x$ & & $\begin{array}{ll}\text { - } & \begin{array}{l}\text { Tactic urbanism } \\
\text { (Placemaking/Pop-ups) }\end{array} \\
\end{array}$ \\
\hline \multirow[b]{2}{*}{$\begin{array}{l}\text { L. Newmarket urbanism } \\
\text { project (United Kingdom, } \\
\text { 2012) [71] }\end{array}$} & \multirow[b]{2}{*}{$\begin{array}{l}\text { To create a sustainable and holistic } \\
\text { vision for Newmarket }\end{array}$} & $\begin{array}{l}\text { - } \quad \begin{array}{l}\text { To establish Newmarket's key issues, } \\
\text { opportunities and challenges }\end{array}\end{array}$ & & $\mathrm{x}$ & & & & & $\mathrm{x}$ & & & & - $\quad$ Scoping workshop \\
\hline & & $\begin{array}{l}\text { - To refine the draft Vision Statements } \\
\text { (from the Scoping Workshop), develop } \\
\text { practical Action Plans, and address } \\
\text { issues of growth and the benefits it } \\
\text { could bring for the town }\end{array}$ & & $\mathrm{x}$ & & & & & & & $\mathrm{x}$ & & $\begin{array}{ll}\text { - } & \text { Enquire by design workshops) } \\
\text { including a colourcoded dot } \\
\text { exercise', public comments } \\
\text { board } \\
\text { - Presentation followed by a } \\
\text { debate }\end{array}$ \\
\hline \multirow{2}{*}{$\begin{array}{l}\text { M. Tōia (New Zealand, } \\
2015)[72]\end{array}$} & \multirow{2}{*}{$\begin{array}{l}\text { Designing a multi-purpose community } \\
\text { facility }\end{array}$} & \multirow{2}{*}{$\begin{array}{l}\text { - To incorporate Mario's cultural values } \\
\text { and its people's needs. }\end{array}$} & $\mathrm{x}$ & $\mathrm{x}$ & & & & & $\mathrm{x}$ & & & & Meetings \\
\hline & & & & & & $\mathrm{x}$ & & & & & $x$ & & $\begin{array}{l}\text { - Commissioning with artists } \\
\text { who undertook the artworks }\end{array}$ \\
\hline \multirow{3}{*}{$\begin{array}{l}\text { N. Greenovate Boston } 2014 \\
\text { Climate Action Plan (Unitited } \\
\text { States, 2014-present) [77] }\end{array}$} & \multirow{3}{*}{ To develop Boston's Climate Action Plan } & \multirow{3}{*}{$\begin{array}{ll}\text { - } & \text { Empower residents and businesses to } \\
\text { take climatate action in their } \\
\text { neighbourhoods } \\
\text { Effectively engage marginalised } \\
\text { populations in urban adaptation } \\
\text { planning }\end{array}$} & $\begin{array}{l}x \\
x\end{array}$ & & & & & $\mathrm{x}$ & & & & & $\begin{array}{ll} & \text { Earth Day event } \\
\text { C Citywide media campaign } & \\
\text { A new website } & \\
\end{array}$ \\
\hline & & & & $\mathrm{x}$ & & & & & & $\mathrm{x}$ & & & $\begin{array}{ll}\text { Community Summit } \\
\vdots & \text { Community yard sale } \\
\text { Civic Academy } \\
\end{array}$ \\
\hline & & & & & & $\mathrm{x}$ & & & & & $\mathrm{x}$ & & Interactive workshop \\
\hline 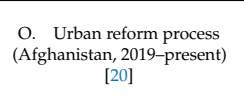 & $\begin{array}{l}\text { To improve the living conditions of } \\
\text { Afghan citizens, who live in informal } \\
\text { housing and slums f(funded by } \\
\text { UN-Habitat) }\end{array}$ & $\begin{array}{ll}\text { - } & \text { Empowers women by providing } \\
\text { access to formal property rights } \\
\text { To develop strategic district action } \\
\text { plans and municipal action plans }\end{array}$ & $\mathrm{x}$ & $\mathrm{x}$ & $\mathrm{x}$ & $\mathrm{x}$ & & & & & & $\mathrm{x}$ & $\begin{array}{l}\text { - Community Development } \\
\text { Councils }\end{array}$ \\
\hline $\begin{array}{l}\text { P. Christchurch Pop-Ups } \\
\text { (New Zealand, 2011) [2] }\end{array}$ & $\begin{array}{l}\text { To swiftly rebuild the city centre after } \\
\text { the } 2011 \text { earthquake }\end{array}$ & $\begin{array}{ll}\text { - } & \text { Rebuilt temporary city structures until } \\
\text { longer-term solutions are found }\end{array}$ & $\mathrm{x}$ & $\mathrm{x}$ & $\mathrm{x}$ & $\mathrm{x}$ & & & & & $\mathrm{x}$ & $\mathrm{x}$ & Placemaking \\
\hline \multirow[t]{2}{*}{$\begin{array}{l}\text { Q. City of Harare proiect } \\
\text { (Zimbabwe, 2014) [19] }\end{array}$} & \multirow[t]{2}{*}{$\begin{array}{l}\text { Mobilising community participation for } \\
\text { inclusive urban development }\end{array}$} & $\begin{array}{ll}\text { - } & \text { To provide a structure for } \\
\text { micro-savings and loans among } \\
\text { members }\end{array}$ & $\mathrm{x}$ & $\mathrm{x}$ & & $\mathrm{x}$ & & & & & & $\mathrm{x}$ & $\begin{array}{l}\text { - } \quad \begin{array}{l}\text { Savings groups (citizen } \\
\text { committees) }\end{array} \\
\text { col }\end{array}$ \\
\hline & & - To facilitate the creation of social bonds & $\mathrm{x}$ & $\mathrm{x}$ & $\mathrm{x}$ & $\mathrm{x}$ & & & & & $\mathrm{x}$ & $\mathrm{x}$ & Weekly meetings \\
\hline $\begin{array}{l}\text { R. Urban Partnerships for } \\
\text { Poverty Reduction (UPRR) } \\
\text { program (Bangladesh, 2014) } \\
\text { [74] }\end{array}$ & $\begin{array}{l}\text { Urban slum upgrading project (funded } \\
\text { by United Nations Development } \\
\text { Program (UNDP) and UN-Habitat and } \\
\text { the UK Government (UKaid)) }\end{array}$ & 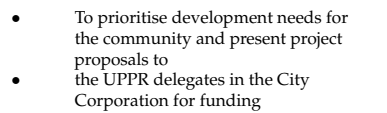 & $\mathrm{x}$ & $\mathrm{x}$ & $\mathrm{x}$ & $\mathrm{x}$ & $\mathrm{x}$ & & & & & $\mathrm{x}$ & $\begin{array}{l}\text { Community Development } \\
\text { Committees (CDCS) }\end{array}$ \\
\hline
\end{tabular}


As observed from the case studies' analysis, all of the projects undertook community engagement activities during the pre-design analysis stage (conceptual design), whilst only a few projects permitted communities to engage in the other phases of development. However, interactive participation is still not overly evident in this stage, as agencies mostly tend to only inform or consult with the public. In many such cases, printed advertisements, media campaigns, websites and blogs, and open-space events have been widely used to publicise development plans and to foster public understanding of the development planning $[59,73]$. Previous research shows that there has been success in applying methods such as public meetings, scoping workshops, forums, interviews, focus groups and questionnaires to gain public feedback for city plans $[2,69,71]$, design proposals $[2,68-70,72]$ and regional policies [68]. In addition, in the Victoria Square development in New Zealand, mobile consultation units with digital information stations were used to assist in eliminating public rejection of the agencies' city proposals [2]. Giving a little more interaction with the public, inclusive projects (mostly in Europe, the USA and New Zealand) have implemented the 'World Café' technique to hold community tables [2]. Additionally, the 'NextCampus' project in Germany developed an online serious game which facilitated the community to play in a virtual site and, thereby, to educate players about the current situation of the existing buildings [67]. The game encouraged the participants to produce the most satisfactory urban planning solution for the upcoming development, and to make 3D simulation models of the buildings according to their expectations. However, this game did not enable players to communicate with the decision-makers or play as groups; thus, there was no space for active participation [67]. Overall, in practice, the informing and consulting methods identified in Figure 2 have been applied in the pre-design analysis stage. Furthermore, at present, it seems that agencies tend mostly not only to inform but also to consult with the public during the pre-design analysis phase, irrespective of the communities' interest in engagement. For this reason, the use of a combination of informing and consulting methods can be seen in the pre-design analysis phase, and these methods consist of both physical and digital/virtual engagement techniques. For example, a public event, an exhibition, media coverage, a website and online forums have been launched in the Greenovate case in the USA [73].

Some of the projects had progressed the public engagement to the briefing stage of urban design. These projects have enhanced community engagement by moving onto the consult, involve and collaborate levels with the public in order to capture clients' / users' needs and expectations. For instance, the Metro Vancouver 2040 project in Canada used several forms of consultation-such as public meetings, workshops, forums, webinars, focus groups and electronic voting - to discuss key regional policies and to seek public comments on them [59]. The community engagement in the Greenovate project went to the involve level using three methods, namely a community summit, a community yard sale and a Civic Academy to effectively engage with marginalised populations in urban adaptation planning [73]. Tactic urbanism, sometimes referred to as placemaking or a pop-up, is a popular approach that enables collaboration with the public in creating design solutions. For example, placemaking was used in Luxor Street in Egypt to develop a tourist street [70], and in Christchurch, after the massive earthquake disruption, to rebuild temporary city structures [2]. Similarly, the Newmarket urbanism project in the UK implemented enquiry by design, adopted from the placemaking approach, to develop practical action plans to accomplish the city's vision statement [71].

From this study's case study analysis, it can be shown that, in most cases, communities are not invited to take part in the later stages of urban development. This could be due to the lack of technical knowledge of locals regarding urban planning. Thus, the final development plan(s)/decisions are made by agencies' practitioners by considering the community inputs that were collected during the first two stages, as appropriate. Participatory budgeting, sometimes known as community development committees/councils (CDCs), has shown potential in empowering communities during the professional design and development stages. This is most evident in emerging economies where inclusive developments 
are funded by international humanitarian organisations. For example, Afghanistan's urban reform process (funded by the UN-Habitat) [20] and the UPPR programme in Bangladesh (funded by the UNDP, UN-Habitat, UKaid) [74] have established CDCs to improve the living conditions of citizens who live in informal housing and slums. Similarly, the Harare city project in Zimbabwe created saving groups to provide a structure for micro-savings and loans among community members [19]. In all three instances, these citizen committees were comprised of women and girls. As such community committees enabled locals to influence the development decisions made by agencies, these groups of people seem to be engaged from the planning to the development of said development projects.

This research shows that community engagement is not considered during the postdevelopment stage, after the completion of the projects' development when the built environments are handed over to the public. In this phase, the community serves as the beneficiary, and hence no participatory methods are tested in practice. One exception is the UPPR programme in Bangladesh, which continued their CDCs even during the post-development stage for the future betterment of their people [74]. However, overall, it seems that less participatory methods have been practically applied and tested for results in the latter stages of urban development (from professional design to post-development in particular).

\section{Discussion}

The purpose of this systematic review paper was to determine the recent applications of existing participatory methods throughout the urban development process. The systematic review conducted in this study revealed that, during the last decade, the application of participatory methods in sustainable urban development has substantially increased, both in terms of the number of papers and in the practice of inclusive methods in different domains such as city planning, urban mobility planning, disaster risk mitigation and community development.

Most of the previous reviews, including both scoping and systematic reviews, have focused on a particular participatory method and its implications in general. Furthermore, these have included neither a valid discussion on the suitability of adapting such methods for the achievement of a specific community engagement purpose nor a valid discussion on specific phase(s) in urban development. For example, Király and Miskolczi [62], in their review, provided an overview of participatory approaches based on SD modelling, but their key findings were based on only four references. Similarly, Xue et al. [17], in their scoping review, concluded on five main modes of multi-sector partnerships, but focused less on the appropriate inclusive methods and tools to achieve diverse partnership goals. The only research contribution that provided an account of the relationship between objectives and techniques for citizen participation was published in 1979 [27], and was focused only on the planning stage. This work [27] was limited to a few conventional engagement techniques and missed most of the innovative and advanced participatory methods, including social media platforms, tactic-urbanism, MSC, ABCD, and PB, which are discussed in the current study.

The study used the five levels of community engagement (inform, consult, involve, collaborate and empower) proposed by the IAP2 [29] as a framework to analyse the current participatory methods. Although it is worth noting that active participation in decisionmaking can only be achieved through collaboration and community-led decision-making, the current review highlights the fact that only a small number of participatory methods and tools are available to collaborate with, and to empower, communities. This study identified 12 purposes of community engagement in urban development that can be mapped to the above five levels. Furthermore, the study found 34 participatory methods that have been used in practice to inform, consult, involve, collaborate and empower communities.

This study further conducted a thorough investigation of 18 case studies to examine the ways in which these methods have currently been applied in practice for various phases of urban development. It examined the purpose of community engagement, the 
level of community engagement and the applied stage of the development. Unlike previous studies which have solely focused on the current practice of local participation in the design and planning phases $[2,27,34,35,41,43,47,52,54,58,59,67-69,73,75]$, this study investigated community engagement throughout the urban development cycle. It is evident that, despite an emphasis on public participation during the planning stages, the actual participation and influence is limited in practice. This can be either because participation often takes place at the end of the planning process, or because the participation processes are mostly based on a pre-existing decision-making structure that is mainly based on economic criteria. Furthermore, in most cases, the public has been completely overlooked in the later stages of development. Consequently, relatively, a smaller number of methods have been tested for the later stages of development. Although participatory approaches in terms of informing communities and/or public consultation are used, this case study review has highlighted that inclusive developments rarely facilitate community-led decision-making.

\subsection{Suggested Model for the Selection of Participatory Methods}

Although a participatory approach to development encourages multi-stakeholder involvement in all of the stages of development, it is evident that community engagement is mostly limited to the inform and consult levels in urban planning, completely overlooking most of the other phases of the development cycle. The key challenges for, and barriers to, a more comprehensive community engagement in risk-sensitive urban design were identified by the authors and published in [18]. Some of the key barriers identified were a lack of understanding of community engagement tools and techniques for specific circumstances, the lack of fair representation from communities, a lack of participation mechanisms to achieve consensus in an efficient manner, a lack of technology for supporting effective community participation, and a lack of communication channels between decision-makers and communities [18]. This paper addressed some aspect of these barriers by seeking a structured method for the selection of participatory methods and tools for the different stages of urban development by the practitioners. These method(s) need to be selected alongside an understanding of the expected level of community engagement, as well as a clear sense of purpose for the community participation in each phase. In order to provide clear guidance on these choices, Figure 8, below, presents an onion model for the selection of the participatory methods for each phase of urban development, as derived from the outcomes of the systematic review and the case-based knowledge developed in this study. This onion model aims to provide a guide for the selection of participatory methods for different stages of urban development in order to help industry practitioners to implement effective community-engagement exercises for inclusive developments.

The onion model proposed for inclusive developments consists of six layers, namely (1) urban development phases, (2) the spectrum of community engagement, (3) the purpose of community engagement, (4) participatory methods, (5) tools and (6) techniques. As proposed in this model, one should peel off each layer of this onion to select the participatory methods which are ideal for engaging communities to achieve the specific purpose of community engagement within an urban development process. This onion model can be customised from one project to another based on the economic, socio-cultural and political contexts inherent within a particular locality where the development is planned.

After deciding the urban development phase in which community participation is required, one needs to define which level of participation is expected from locals (i.e., inform, consult, involve, collaborate, or empower). Following this decision, it is essential to understand the true purpose of the engagement that one expects to achieve. The study identified 12 purposes of community engagement in urban development that serve as the content of the third layer. Next, there are dedicated participatory methods within each purpose of community engagement. The mapping of participatory methods into the spectrum of community engagement provides the basis for this selection, as it places the participatory methods into different community engagement purposes. However, when selecting community engagement methods, one could consciously choose methods that have more space 
for true community involvement, rather than a basic inform and consult approach. For example, if the requirement is to inform communities, it is advisable to use social media platforms or public meetings which at least provide a space for communities to have a voice, rather than one-way information flows such as websites, videos, or printed materials.

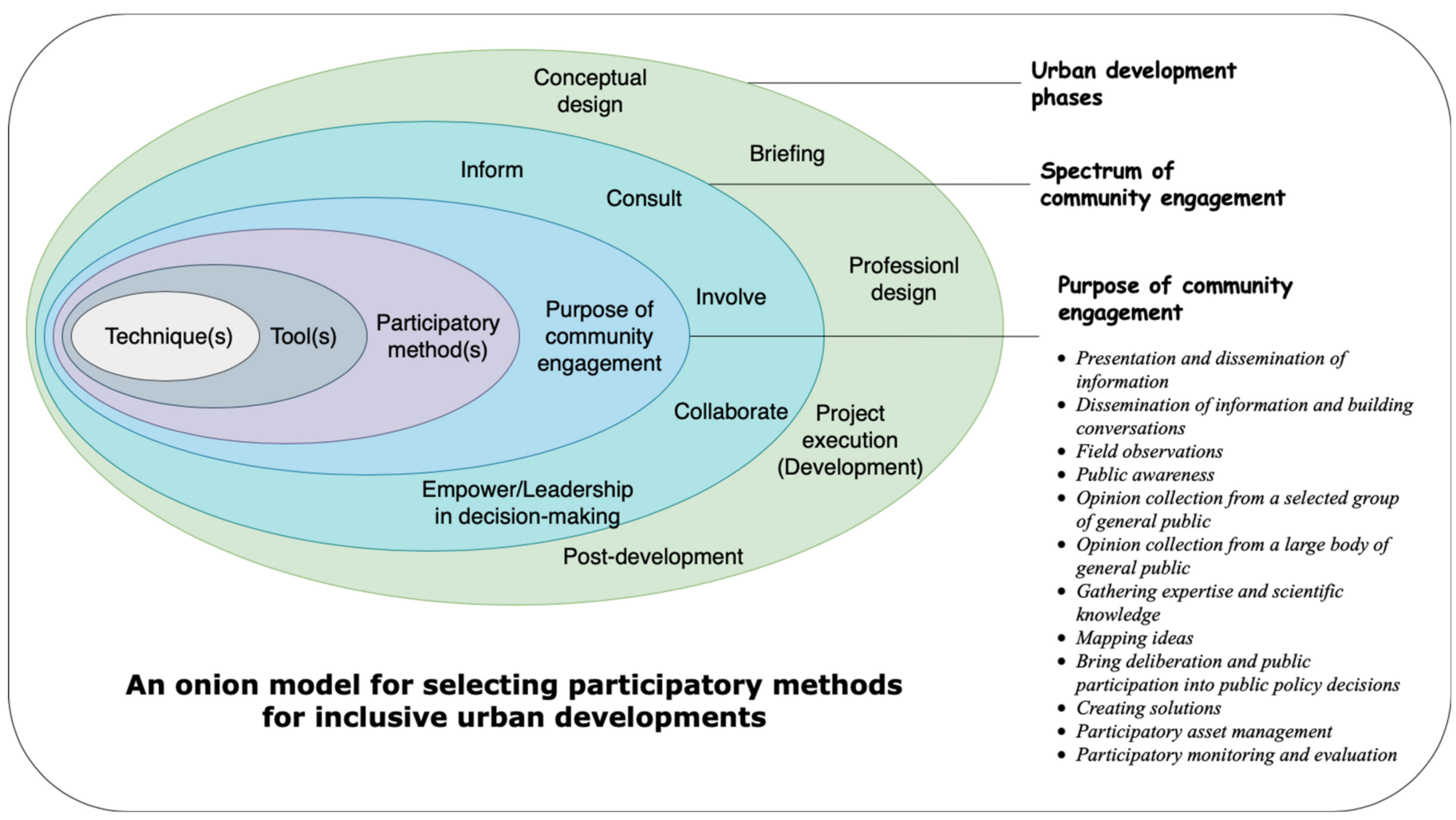

Figure 8. An onion model for the selection of participatory methods for inclusive developments (source: the authors). Note: First layer—urban development phases; second layer—the spectrum of community engagement; third layer—the 12 purposes of community engagement; fourth layer-participatory methods; fifth layer-device/app that enables the implementation of the selected method; sixth/final layer-procedure for carrying out a particular task.

As presented in Table 2, there can be different tools for implementing each participatory method, and these need to be carefully selected. For example, if one needs to inform a larger body of people about an upcoming urban development, social media can be selected as the method and Facebook as the tool of implementation. Similarly, if the requirement is financial resource allocation for a proposed development, practitioners can implement participatory budgeting with the use of 'Cobudget', which is a tool that enables people to get involved in decision-making by allocating funds to the proposals they like. Lastly, it is important to understand how the selected tool(s) will be implemented in order to achieve the desired outcome; this is referred to as the 'technique' in the onion model.

\subsection{Impact of Covid-19 on Community Engagement}

It has been observed that current community-engaged decision-making approaches for urban development can be additionally challenging due to the adverse impacts of the current Covid-19 pandemic situation. For example, physical participatory approaches such as public meetings, community mapping, site visits, place-making and open house events may be discouraged due to social distancing requirements, public gathering restrictions and other safety measures. This could be further exacerbated by the limited finance and support available for community engagement due to the current global economic recession. Public interest in collaboration may also be derelict due to the loss of social gathering platforms. Therefore, it is currently good timing to investigate innovative approaches that exploit social media and other virtual applications in the facilitation of active community 
participation. The rise of the internet and digital tools is revolutionising community engagement in urban planning and development, in particular in the engagement of disinterested or exhausted communities and young people. However, care needs to be taken to ensure that vulnerable communities, especially in emerging economies, have access to such digital platforms, as well as an adequate knowledge of using such digitally driven community engagement solutions in order to avoid further exacerbation of the current situation of community exclusion in decision-making.

\subsection{Study Limitations}

Despite having followed a systematic literature review using PRISMA, there could still be studies that have not been considered in this review due to the unavailability of the full-text. In addition, this review only identified articles published after the year 2000, as its purpose was to find the latest applications of participatory methods, particularly in the urban development domain. Only articles written in English within the indexed sources were included.

\section{Conclusions and Future Research Directions}

This systematic review aimed at understanding and mapping the existing participatory methods into different purposes of public participation for the urban development process, in particular. A central paradox of this literature is that while there is a range of suggested methods for industry practitioners to use for community engagement, there is very little empirical evidence of what works for which purpose and when. The decision to engage in, or require, citizen participation must be followed by a detailed identification of the desired purposes. Once the community engagement purposes are well defined, then the search for a method may begin. A combination of methods may also work well either in terms of achieving several purposes together or when targeting communities with different levels of social capital. Furthermore, the methods need to be carefully selected whilst considering the current understanding and experience of communities in participatory approaches. Another, more general, conclusion is that there is no single method that is able to satisfy all 12 purposes of community engagement. Thus, there is no participatory method that emerges as the most desirable in all situations; rather, the best method is dependent upon the situation (i.e., the specific urban development phase) and the purpose. By using methods mapped under each engagement level (i.e., inform to empower) gradually and systematically, the resultant inclusive development project could pursue equitable, community-led decision-making.

It is hoped that this study's findings will make a contribution to the subject of participatory approaches, and that they will help governments, community organisations, researchers, policymakers and other institutions (such as NGOs) who are working at the ground level to make informed discussions with communities in order to achieve equitable, inclusive urban developments. The interpretive case studies' analysis provides highlights of the industry practice of using inclusive developments that might be generalised beyond the selected cases.

Possible research questions that could build on the proposed community engagement methods in this paper includes: How do varying economic, socio-cultural and political conditions influence inclusive developments? What community engagement methods are most suitable for what specific contexts? How can one capture community transformation in different levels of engagement when one is applying these community engagement methods? What novel participatory methods will be more effective in a pandemic situation like Covid-19?

Author Contributions: Conceptualisation, D.G.; systematic literature review and analysis (methodology), D.G.; writing — original draft preparation, D.G.; writing—review and editing, T.F., D.G. and K.K.; visualisation, D.G.; supervision, T.F. and K.K.; funding acquisition, T.F. All authors have read and agreed to the published version of the manuscript. 
Funding: This research was funded by the Global Challenges Research Fund (GCRF) and the Economic and Social Research Council (ESRC), grant number ES/T003219/1, entitled “Technology Enhanced Stakeholder Collaboration for Supporting Risk-Sensitive Sustainable Urban Development".

Conflicts of Interest: The authors declare no conflict of interest. The funders had no role in the design of the study; in the collection, analyses, or interpretation of data; in the writing of the manuscript, or in the decision to publish the results.

\section{References}

1. United Nations Department of Economic and Social Affairs Population Division. World Urbanization Prospects: The 2018 Revision, Online Edition. Available online: https://population.un.org/wup/Publications/Files/WUP2018-Highlights.pdf (accessed on 14 March 2021).

2. Savic, B. Community Engagement in Urban Planning and Development; The Prince's Regeneration Trust: London, UK, 2015.

3. European Environment Agency—Swiss Federal Office for the Environment. Urban Sprawl in Europe; Publications Office of the European Union: Luxembourg, 2016.

4. Avis, W.R. Urban Governance (Topic Guide); GSDRC, University of Birmingham: Birmingham, UK, 2016.

5. Argüeso, D.; Evans, J.P.; Fita, L.; Bormann, K.J. Temperature response to future urbanization and climate change. Clim. Dyn. 2013, 42, 2183-2199. [CrossRef]

6. Schwarz, N.; Bauer, A.; Haase, D. Assessing climate impacts of planning policies-An estimation for the urban region of Leipzig (Germany). Environ. Impact Assess. Rev. 2011, 31, 97-111. [CrossRef]

7. Adelekan, I.; Johnson, C.; Manda, M.; Matyas, D.; Mberu, B.; Parnell, S.; Pelling, M.; Satterthwaite, D.; Vivekananda, J. Disaster risk and its reduction: An agenda for urban Africa. Int. Dev. Plan. Rev. 2015, 37, 33-43. [CrossRef]

8. Bhatta, B. Causes and consequences of urban growth and sprawl. In Analysis of Urban Growth and Sprawl from Remote Sensing Data; Springer: Berlin/Heidelberg, Germany, 2010; pp. 17-36.

9. Bhatta, B.P.; Pandey, R.K. Bhaktapur urban flood related disaster risk and strategy after 2018. J. APF Command Staff Coll. 2020, 3 , 72-89. [CrossRef]

10. Sharma, A.; Srujan, A.; Shaw, R. Climate disaster resilience: Focus on coastal urban cities in Asia. Asian J. Environ. Disaster Manag. 2011, 1, 1-16. [CrossRef]

11. Badri, S.A.; Asgary, A.; Eftekhari, A.; Levy, J. Post-disaster resettlement, development and change: A case study of the 1990 Manjil earthquake in Iran. Disasters 2006, 30, 451-468. [CrossRef]

12. Godamunne, N. Development and displacement: The national involuntary resettlement policy (NIRP) in practice. Sri Lanka J. Soc. Sci. 2012, 35, 37-50. [CrossRef]

13. Hambati, H. Weathering the storm: Disaster risk and vulnerability assessment of informal settlements in Mwanza city, Tanzania. Int. J. Environ. Stud. 2013, 70, 919-939. [CrossRef]

14. Muggah, R. Through the developmentalist's looking glass: Conflict-induced displacement and involuntary resettlement in Colombia. J. Refug. Stud. 2000, 13, 133-164. [CrossRef]

15. Obeng-Odoom, F. Land reforms in Africa: Theory, practice, and outcome. Habitat Int. 2012, 36, 161-170. [CrossRef]

16. Robinson, W.C. Risks and Rights: The Causes, Consequences, and Challenges of Development-Induced Displacement; The Brookings Institution-SAIS Project on Internal Displacement: Washington, DC, USA, 2003.

17. Xue, Y.; Temeljotov-Salaj, A.; Engebo, A.; Lohne, J. Multi-sector partnerships in the urban development context: A scoping review. J. Clean. Prod. 2020, 268, 122291. [CrossRef]

18. Geekiyanage, D.; Fernando, T.; Keraminiyage, K. Assessing the state of the art in community engagement for participatory decision-making in disaster risk-sensitive urban development. Int. J. Disaster Risk Reduct. 2020, 51, 101847. [CrossRef] [PubMed]

19. Shand, W. Efficacy in action: Mobilising community participation for inclusive urban development. Urban Forum 2018, 29, 109-126. [CrossRef]

20. UN-Habitat. Promoting Inclusive, Safe, Resilient and Sustainable Afghan Cities for All. Available online: https: // sustainabledevelopment.un.org/partnership/?p=30477 (accessed on 21 March 2021).

21. Apronti, P.; Osamu, S.; Otsuki, K.; Kranjac-Berisavljevic, G. Education for Disaster Risk Reduction (DRR): Linking theory with practice in Ghana's basic schools. Sustainability 2015, 7, 9160-9186. [CrossRef]

22. United Nations. United Nations Conference on Housing and Sustainable Urban Development (Habitat III) Regional Report for Africa: Transformational Housing and Sustainable Urban Development in Africa; United Nations: Nairobi, Kenya, 2016.

23. Moher, D.; Shamseer, L.; Clarke, M.; Ghersi, D.; Liberati, A.; Petticrew, M.; Shekelle, P.; Stewart, L.A. Preferred reporting items for systematic review and meta-analysis protocols (PRISMA-P) 2015 statement. Syst. Rev. 2015, 4, 1-9. [CrossRef] [PubMed]

24. Page, M.J.; McKenzie, J.E.; Bossuyt, P.M.; Boutron, I.; Hoffmann, T.C.; Mulrow, C.D.; Shamseer, L.; Tetzlaff, J.M.; Moher, D. Updating guidance for reporting systematic reviews: Development of the PRISMA 2020 statement. Syst. Rev. 2021, 10, 1-11. [CrossRef]

25. Lee, A.S. Philosophy and method: Making interpretive research interpretive. In The Routledge Companion to Management Information Systems; Routledge: London, UK, 2017; pp. 30-46.

26. Lindenau, M.; Böhler-Baedeker, S. Citizen and Stakeholder Involvement: A Precondition for Sustainable Urban Mobility. Transp. Res. Procedia 2014, 4, 347-360. [CrossRef] 
27. Glass, J.J. Citizen participation in planning: The relationship between objectives and techniques. J. Am. Plan. Assoc. 1979, 45, 180-189. [CrossRef]

28. Community Places. Community Planning Toolkit; Community Places: Belfast, UK, 2014.

29. International Association for Public Participation. IAP2 Spectrum of Public Participation. Available online: https://iap2.org.au/ wp-content/uploads/2020/01/2018_IAP2_Spectrum.pdf (accessed on 15 March 2021).

30. Queensland Government. Community Engagement Techniques; Queensland Government: Queensland, Austrailia, 2010.

31. Tamarack Institute. Index of Community Engagement Techniques; Tamarack Institute: Waterloo, ON, Canada, 2017.

32. Aslin, H.; Brown, V. Towards Whole of Community Engagement: A Practical Toolkit; Murray-Darling Basin Commission: Canberra, Australia, 2004.

33. Customer Service-Communication and Consultation Services. In Community Engagement Framework 2013-2018; The City of Newcastle: Newcastle, Australia, 2012.

34. Münster, S.; Georgi, C.; Heijne, K.; Klamert, K.; Noennig, J.R.; Pump, M.; Stelzle, B.; van der Meer, H. How to involve inhabitants in urban design planning by using digital tools? An overview on a state of the art, key challenges and promising approaches. Procedia Comput. Sci. 2017, 112, 2391-2405. [CrossRef]

35. Brown, G.; Chin, S.Y.W. Assessing the effectiveness of public participation in neighbourhood planning. Plan. Pract. Res. 2013, 28, 563-588. [CrossRef]

36. Organisation for Economic Co-Operation and Development. Stakeholder Involvement in Decision Making: A Short Guide to Issues, Approaches and Resources; OECD: Paris, France, 2015.

37. Basco-Carrera, L.; Warren, A.; van Beek, E.; Jonoski, A.; Giardino, A. Collaborative modelling or participatory modelling? A framework for water resources management. Environ. Model. Softw. 2017, 91, 95-110. [CrossRef]

38. Hernantes, J.; Maraña, P.; Gimenez, R.; Sarriegi, J.M.; Labaka, L. Towards resilient cities: A maturity model for operationalizing resilience. Cities 2019, 84, 96-103. [CrossRef]

39. Rollason, E.; Bracken, L.J.; Hardy, R.J.; Large, A.R.G. Evaluating the success of public participation in integrated catchment management. J. Environ. Manag. 2018, 228, 267-278. [CrossRef]

40. Chini, C.M.; Canning, J.F.; Schreiber, K.L.; Peschel, J.M.; Stillwell, A.S. The green experiment: Cities, green stormwater infrastructure, and sustainability. Sustainability 2017, 9, 105. [CrossRef]

41. Rodríguez, L.O.; Cisneros, E.; Pequeño, T.; Fuentes, M.T.; Zinngrebe, Y. Building adaptive capacity in changing social-ecological systems: Integrating knowledge in communal land-use planning in the Peruvian Amazon. Sustainability 2018, 10, 511. [CrossRef]

42. Perrone, A.; Inam, A.; Albano, R.; Adamowski, J.; Sole, A. A participatory system dynamics modeling approach to facilitate collaborative flood risk management: A case study in the Bradano River (Italy). J. Hydrol. 2020, 580, 124354. [CrossRef]

43. Mulligan, J.; Bukachi, V.; Gregoriou, R.; Venn, N.; Ker-Reid, D.; Travers, A.; Benard, J.; Olang, L.O. Participatory flood modelling for negotiation and planning in urban informal settlements. Proc. Inst. Civ. Eng. Eng. Sustain. 2019, 172, 354-371. [CrossRef]

44. Sharifi, A. A critical review of selected tools for assessing community resilience. Ecol. Indic. 2016, 69, 629-647. [CrossRef]

45. Parsons, M.; Glavac, S.; Hastings, P.; Marshall, G.; McGregor, J.; McNeill, J.; Morley, P.; Reeve, I.; Stayner, R. Top-down assessment of disaster resilience: A conceptual framework using coping and adaptive capacities. Int. J. Disaster Risk Reduct. 2016, 19, 1-11. [CrossRef]

46. Bowen, F.; Newenham-Kahindi, A.; Herremans, I. Engaging the Community: A Systematic Review; University of Calgary: Calgary, $\mathrm{AB}$, Canada, 2008.

47. Hardoy, J.; Gencer, E.; Winograd, M. Participatory planning for climate resilient and inclusive urban development in Dosquebradas, Santa Ana and Santa Tomé. Environ. Urban. 2019, 31, 33-52. [CrossRef]

48. Rosenstock, T.S.; Lamanna, C.; Chesterman, S.; Hammond, J.; Kadiyala, S.; Luedeling, E.; Shepherd, K.; DeRenzi, B.; van Wijk, M.T. When less is more: Innovations for tracking progress toward global targets. Curr. Opin. Environ. Sustain. 2017, 26-27, 54-61. [CrossRef]

49. Pagano, A.; Pluchinotta, I.; Pengal, P.; Cokan, B.; Giordano, R. Engaging stakeholders in the assessment of NBS effectiveness in flood risk reduction: A participatory system dynamics model for benefits and co-benefits evaluation. Sci. Total Environ. 2019, 690, 543-555. [CrossRef]

50. Hedelin, B.; Evers, M.; Alkan-Olsson, J.; Jonsson, A. Participatory modelling for sustainable development: Key issues derived from five cases of natural resource and disaster risk management. Environ. Sci. Policy 2017, 76, 185-196. [CrossRef]

51. Ricciardi, F.; De Bernardi, P.; Cantino, V. System dynamics modeling as a circular process: The smart commons approach to impact management. Technol. Forecast. Soc. Chang. 2020, 151, 119799. [CrossRef]

52. McEvoy, S.; van de Ven, F.H.M.; Blind, M.W.; Slinger, J.H. Planning support tools and their effects in participatory urban adaptation workshops. J. Environ. Manag. 2018, 207, 319-333. [CrossRef]

53. Saadallah, D.M. Utilizing participatory mapping and PPGIS to examine the activities of local communities. Alex. Eng. J. 2020, 59, 263-274. [CrossRef]

54. Kaczmarek, T.; Wójcicki, M. Participation in Public Consultations on Spatial Planning Documents. The Case of Poznań City. Quaest. Geogr. 2016, 35, 71-81. [CrossRef]

55. Raymond, C.M.; Frantzeskaki, N.; Kabisch, N.; Berry, P.; Breil, M.; Nita, M.R.; Geneletti, D.; Calfapietra, C. A framework for assessing and implementing the co-benefits of nature-based solutions in urban areas. Environ. Sci. Policy 2017, 77, 15-24. [CrossRef] 
56. Martín, E.G.; Giordano, R.; Pagano, A.; van der Keur, P.; Costa, M.M. Using a system thinking approach to assess the contribution of nature based solutions to sustainable development goals. Sci. Total Environ. 2020, 738, 139693. [CrossRef]

57. Könst, A.; Van Melik, R.; Verheul, W.J. Civic-led public space: Favourable conditions for the management of community gardens. Town Plann. Rev. 2018, 89, 575-595. [CrossRef]

58. Organisation for Economic Co-Operation and Development. Chapter 3. Citizen participation in land-use planning and urban regeneration in Korea. In The Governance of Land Use in Korea: Urban Regeneration; OECD: Paris, France, 2019.

59. Pickering, T.; Minnery, J. Scale and public participation: Issues in metropolitan regional planning. Plan. Pract. Res. 2012, 27, 249-262. [CrossRef]

60. Stańczuk-Gałwiaczek, M.; Sobolewska-Mikulska, K.; Ritzema, H.; van Loon-Steensma, J.M. Integration of water management and land consolidation in rural areas to adapt to climate change: Experiences from Poland and the Netherlands. Land Use Policy 2018, 77, 498-511. [CrossRef]

61. Pejic Bach, M.; Tustanovski, E.; Ip, A.W.; Yung, K.-L.; Roblek, V. System dynamics models for the simulation of sustainable urban development: A review and analysis and the stakeholder perspective. Kybern. Int. J. Syst. Cybern. 2019, 49, 460-504. [CrossRef]

62. Király, G.; Miskolczi, P. Dynamics of participation: System dynamics and participation-An empirical review. Syst. Res. Behav. Sci. 2019, 36, 199-210. [CrossRef]

63. Andersen, D.F.; Vennix, J.A.; Richardson, G.P.; Rouwette, E.A. Group model building: Problem structuring, policy simulation and decision support. J. Oper. Res. Soc. 2007, 58, 691-694. [CrossRef]

64. Stave, K.A. Using system dynamics to improve public participation in environmental decisions. Syst. Dyn. Rev. J. Syst. Dyn. Soc. 2002, 18, 139-167. [CrossRef]

65. Hovmand, P.S. Community Based System Dynamics; Springer: Berlin/Heidelberg, Germany, 2014; pp. 1-104.

66. Bouw, M.; Thoma, D. Economic Resilience Through Community-Driven (Real Estate) Development in Amsterdam-Noord; Springer: Englewood, NJ, USA, 2019; pp. 119-127.

67. Poplin, A. Playful public participation in urban planning: A case study for online serious games. Comput. Environ. Urban Syst. 2012, 36, 195-206. [CrossRef]

68. Moghaddam, S.N.M.; Rafieian, M. From the kingdom lash to participation: The tale of urban planning in Iran. Soc. Sci. Humanit. Open 2020, 2, 100022. [CrossRef]

69. Jesse, W. Why the Public Voice Matters in Urban Mobility Planning: Lessons from Brazil. Available online: https://thecityfix. $\mathrm{com} / \mathrm{blog} /$ public-participation-sustainable-urban-mobility-plan-brazil-cities-pac-jesse-worker/ (accessed on 14 March 2021).

70. Abd Elrahman, A.S. Tactical ubanism "A pop-up local change for Cairo's built environment". Procedia Soc. Behav. Sci. 2016, 216, 224-235. [CrossRef]

71. Prince's Foundation for Building Community. Newmarket Enquiry by Design Workshop Report; Prince's Foundation for Building Community: London, UK, 2012.

72. Auckland Design Manual. Tōia Multi-Purpose Community Facility; Auckland Design Manual: Auckland, New Zealand, 2015.

73. Kirshen, P.; Ballestero, T.; Douglas, E.; Miller Hesed, C.D.; Ruth, M.; Paolisso, M.; Watson, C.; Giffee, P.; Vermeer, K.; Bosma, K. Engaging vulnerable populations in multi-level stakeholder collaborative urban adaptation planning for extreme events and climate risks-A case study of East Boston USA. J. Extrem. Events 2018, 5, 1850013. [CrossRef]

74. Walters, P. The limits to participation: Urban poverty and community driven development in Rajshahi City, Bangladesh. Community Dev. 2018, 49, 539-555. [CrossRef]

75. Kyriakidis, C. Citizen and city: Issues related in public participation in the process of spatial planning. In Proceedings of the 3rd National Conference of Planning and Regional Development, University of Thessaly, Volos, Greece, 27-30 September 2012; pp. 27-30. 